\title{
Sermaye Piyasası Kanunu'nda Piyasa Dolandırıcılığı ve Güveni Kötüye Kullanma Suçları İçin Öngörülen Etkin Pişmanlık Düzenlemesi ve Uygulamada Karşılaşılan Sorunlar*
}

\author{
Effective Repentance Regulation For Market Manipulation And Abuse \\ Of Confidence Crimes in Capital Market Law and Problems Encountered \\ in Practice
}

\begin{abstract}
Ahmet Tok $^{* *}$ iD
\end{abstract}
\section{öz}

6362 sayılı Sermaye Piyasası Kanunu’nda piyasa dolandırıcılığı ve örtülü kazanç aktarımı suçları açısından etkin pişmanlık düzenlemelerine yer verilmiştir. Bu çerçevede, işlem bazlı piyasa dolandırıcılığı kapsamına giren fiillerde bulunanların elde ettikleri menfaatin iki katını soruşturma başlamadan önce Hazine'ye ödemeleri halinde bu suçtan dolayı haklarında cezaya hükmolunmaz. Bununla birlikte ödeme soruşturma başladıktan sonra yapılırsa, verilecek cezanın yarısı indirilir, kovuşturma evresinde hüküm verilinceye kadar yapılacak ödemelerde ise verilecek ceza üçte biri oranında indirilir. Örtülü kazanç aktarımı suçu açısından ise fail tarafından SPK’nın 21/4 maddesinde öngörülen tutar ödendikten sonra aktarılan tutarın iki katının soruşturma başlamadan önce Hazine’ye ödenmesi halinde bu suçtan dolayı cezaya hükmolunmaz. Bu tutarın soruşturma sırasında ödenmesi halinde verilecek cezanın yarısı indirilir, kovuşturma evresinde hüküm verilinceye kadar ödendiği takdirde ise, verilecek ceza üçte biri oranında indirilir. İşbu çalışmamızda sermaye piyasası mevzuatındaki etkin pişmanlık hükümlerinin uygulanma usulü, suçlara özgü hususiyetler, uygulama sorunları bağlamında soruşturma öncesi etkin pişmanlık halinde suç duyurusunda bulunulması ve savcının dava açıp açmamasına ilişkin tartışmalar, etkin pişmanlık ve iştirak ilişkisi, failin menfaat elde etmemesi durumunun hükmün uygulanmasına etkisi, failler tarafından Hazine’ye ödeme yapılmasının yerindeliği analiz edilmeye çalışılmıştır.

Anahtar Kelimeler: Sermaye piyasası kanunu, Etkin pişmanlık, Piyasa dolandırıcılı̆̆ı, Örtülü kazanç aktarımı, Güveni kötüye kullanma.

* İşbu çalışmada dermeyan edilen görüşler, yazarın şahsi görüşleri olup, mensup olduğu kurumu bağlamaz.

** Dr., Sermaye Piyasası Kurulu, Başuzman Hukukçu, Orcid: 0000-0003-2804-9255.

Sorumlu Yazar/Correspondence Author: Ahmet Tok

E-posta/E-mail: ahmet.tok@spk.gov.tr

Geliș Tarihi/Received: $\quad 02.09 .2021$

Kabul Tarihi/Accepted: $\quad$ 27.11.2021 


\section{ABSTRACT}

The Capital Market Law numbered 6362 has effective repentance regulations for market manipulation and disguised transfer pricing crimes. In this context, if those who commit the crime within the scope of transaction-based market manipulation and pays to the Treasury an amount which is twice of the benefit he/she has obtained or has caused to be obtained, not being less than five hundred thousand Turkish Liras, no penalty shall be imposed if the payment has been made before the investigation starts. The penalty to be imposed shall be reduced by half, if the payment is made during the phase of investigation and the penalty to be imposed shall be reduced by one third, if the payment is made during the phase of prosecution until the judgement has been rendered. In terms of disguised transfer pricing crime, in cases where the person who has committed the crime of abuse of confidence displays effective repentance and makes the payment mentioned in the fourth paragraph of Article 21 along with the payment amounting to twice of this payment to the Treasury, no penalty shall be imposed if the payment has been made before the investigation starts. The penalty to be imposed shall be reduced by half, if the payment is made during the phase of investigation and the penalty to be imposed shall be reduced by one third, if the payment is made during the phase of prosecution until the judgement has been rendered. In this study, the method of application of the provisions of effective repentance in the capital market legislation, the particularities of the crimes, written application to be made by the Board in effective repentance before the investigation and the discussions on whether the prosecutor should file a lawsuit in the context of the implementation problems, the relationship of effective repentance and crimes committed in participation, the effect of the perpetrator's lack of benefit on the implementation of the provision, the legitimacy of payment of perpetrators to the Treasury will be analyzed.

Keywords: Capital market law, Effective repentance, Market manipulation, Illegal transfer pricing, Abuse of confidence.

\section{GENEL OLARAK ETKIN PIŞMANLIK}

\section{A. ETKIN PIŞMANLIK KURUMU VE ÖZELLIKLERI}

Etkin pişmanlığın tanımına ilişkin olarak doktrinde görüş birliği bulunmamakla birlikte etkin pişmanlık; şüpheli ve/veya sanıkların işledikleri suçtan/suçlardan dolayı özgür iradeleriyle suçun işlenip tamamlanmasının, bir başka deyişle suçun neticesinin gerçekleşmesinin ardından pişman olmaları, suç teşkil eden fiilin meydana getirdiği zararı, ziyanı ya da olumsuzlukları izale etmeleri ve ceza adaletine böylece olumlu ve etkin davranışlarıyla katkı sağlamaları halinde cezasızlık ya da cezada indirime ilişkin hükümlerin tatbiki sonucunu doğuran bir ceza hukuku kurumu olarak tavsif edilebilir ${ }^{1}$.

Etkin pişmanlık, suçun neticesinin ikmalinden sonra ortaya çıkan bazı şartların varlığı durumunda kimi suçlar bakımından cezayı tamamen kaldıran veya cezada indirim yapılmasını sağlayan sebepler

1 İzzet Özgenç, Türk Ceza Hukuku Genel Hükümler, (17. Baskı, Seçkin 2021) 576; Mahmut Koca ve İlhan Üzülmez, Türk Ceza Hukuku Genel Hükümler, (14. Bask1, Seçkin 2021) 444-445; Mustafa Arslantürk, Etkin Pişmanlık Vazgeçme Cezasızlı (Seçkin 2018) 22; İbrahim Özer, 'Türk Ceza Hukukunda Etkin Pişmanlı' (Yüksek Lisans Tezi, Selçuk Üniversitesi 2011) 6. Etkin pişmanlık kurumunun 765 sayılı mülga Türk Ceza Kanunu ile 5237 sayılı Türk Ceza Kanunu dönemindeki tanımları ve kurumun tarihi gelişimi hakkında bkz Ensar Baki, 'Türk Ceza Kanununda Etkin Pişmanlık' (2016) (2) Yıldırım Beyazıt Hukuk Dergisi 27, 29-31 <https://dergipark.org.tr/tr/download/article-file/227124> Erişim Tarihi 1 Eylül 2021. 
olarak tavsif edilmekte olup, şartların gerçekleşmesi halinde kişiye ya hiç ceza verilmemekte ya da cezasında indirim yapılmaktadır. Bunlar; cezayı kaldıran ya da cezada indirim yapılmasını gerektiren şahsi sebep olarak adlandırılmakta olup, suç tamamlandıktan sonra failin, haksızlığın neticelerini mümkün olduğunca gidermeye çalışarak gösterdiği etkin pişmanlık, cezayı kaldıran ya da azaltan şahsi sebep olarak kabul edilmektedir². Nitekim kanun koyucu malvarlığına karşı suçlarda etkin pişmanlığı düzenlediği 5237 sayılı Türk Ceza Kanunu’nda3 (TCK) md. 168 hükmünün gerekçesinde, bu düzenlemenin cezada indirim yapılmasını gerektiren bir şahsi sebep niteliğinde olduğunu açıkça belirtmiştir4.

Etkin pişmanlık halinde, fail tarafından gerçekleştirilen hareket ve husule gelen netice dış dünyada hiç ortaya çıkmamış gibi kabul edilmemekte, hareket ve netice varlığını korumakta, bir başka ifade ile fiil, suç olma özelliğini devam ettirmekte ancak gösterilen pişmanlık nedeniyle fail hakkında ceza verilmemekte ya da failin cezasında indirim yapılmaktadır ${ }^{5}$.

Etkin pişmanlık kurumunun uygulama alanı bulabilmesi için kanunda öngörülmesi, suça ilişkin neticenin gerçekleşmiş olması, failin suç nedeniyle pişman olarak suçun neticelerinin etkilerini ortadan kaldırmaya yönelik davranışlarda bulunması ve davranışların belli bir zaman diliminde gerçekleştirilmesi şeklinde dört şartın meydana gelmesi aranmaktadır ${ }^{6}$.

Etkin pişmanlık kurumunun TCK kapsamında ne şekilde düzenlendiği aşağıda açıklanacak olmakla birlikte kanun koyucunun iradesi doğrultusunda sadece TCK kapsamında değil tüm özel ceza kanunlarında, bir başka deyişle özel ceza hükümleri ihtiva eden kanunlarda da bu kuruma yer verilebileceği açıktır. Nitekim inceleme konumuz olan işlem bazlı piyasa dolandırıcılı̆̆ı ve örtülü kazanç aktarımı suçları, 6362 sayılı Sermaye Piyasası Kanunu’nda ${ }^{7}$ (SPK/Kanun) düzenlenen suçlar olup, kanun koyucu tarafından, anılan suçlara özgü hususiyetler ve sermaye piyasasına ilişkin özellikler de dikkate alınarak TCK’dan farklı şekilde işleyen bir etkin pişmanlık kurumu öngörülmüştür.

2 Günal Kurşun, Ceza Muhakemesinde Hüküm, (Seçkin 2016) 151; Veli Özer Özbek, Ekonomi Ceza Hukuku Birinci KitapGenel Hükümler (2. Baskı, Seçkin 2021) 131-132. Etkin pişmanlık türleri ve özellikleri hakkında bkz. ibid 127-132.

3 Türk Ceza Kanunu, Kanun Numarası: 5237, Kabul Tarihi: 26.9.2004, RG. 12.10.2004/25611.

4 Yasemin Baba, 'Türk Ceza Kanununda Etkin Pişmanlık', (Yüksek Lisans Tezi, İstanbul Üniversitesi 2011$) 25$.

5 Fail suç tamamlandıktan sonra etkin pişmanlık gösterebilir. İşlenmiş ve tamamlanmış olan suç, bu pişmanlık dolayısıyla işlenmemiş hale irca edilememektedir. Ancak işlenen haksızlığın neticeleri fail tarafından mümkün olduğunda izale edilmektedir. Özgenç, (n 1) 240. Kural olarak etkin pişmanlığın ceza sorumluluğu üzerinde bir etkisi yoktur. Etkin pişmanlık, TCK’da genel hükümler arasında ceza sorumluluğunu etkileyen bir hal olarak düzenlenmemiştir. Bununla birlikte TCK’nın özel hükümler kısmında bazı suç tipleri bakımından etkin pişmanlığa ilişkin düzenlemelere yer verilmiştir. Gönüllü vazgeçme gibi etkin pişmanlık da haksızlığın unsurları ve kusurluluk dışında yer almaktadır. Koca ve Üzülmez, (n 1) 445.

6 Evrim Yıldırım, 'Sermaye Piyasası Suçları Açısından Etkin Pişmanlık', Sermaye Piyasası Kurulu Yeterlik Etüdü (Hizmete Özel), (2013) 4-5. Yine etkin pişmanlığın unsurları ve detaylı değerlendirmeler için bkz Baki, (n 1), 42-48. Etkin pişmanlığın özellikle malvarlığına karşı suçlar bakımından unsurları için bkz. M. Emin Artuk, Ahmet Gökcen, M. Emin Alşahin ve Kerim Çakır, Ceza Hukuku Özel Hükümler, (19. Baskı, Adalet 2021) 693-695.

7 Sermaye Piyasası Kanunu, Kanun Numarası: 6362, Kabul tarihi: 6.12.2012, RG 30.12.2012/28513. 


\section{B. ETKIN PIŞMANLIĞIN TÜRK CEZA KANUNU'NDA DÜZENLENME ŞEKLi}

TCK’da yer alan etkin pişmanlık hükümlerinde, suç neticesi de dâhil olmak üzere tüm unsurlarıyla oluştuktan sonra failin ortaya çıkan zararlı sonucun etkilerini azaltmaya yönelik eylemlerine değer atfedilmektedir. TCK'da etkin pişmanlık, tamamlanmış suçlar bakımından öngörülmüş olup, bu müessese kanunun genel hükümler kısmında düzenlenmediğinden, yalnızca kanun koyucunun belirlemiş olduğu suçlar bakımından uygulanmaktadır.

TCK'da yalnızca kanun koyucunun belirlemiş olduğu bazı suçlar bakımından, etkin pişmanlık maddesi şeklinde ayrı bir madde olarak veya suçun düzenlendiği maddenin içinde ayrı fikra olarak veyahut bölümün sonunda ayrı bir maddede bölümdeki suçlar zikredilmek suretiyle düzenlemiş olup, genellikle suç nedeniyle mağdurdan elde edilen menfaatin ${ }^{8}$ ya da mağdurun maruz kalacağ 1 zararın $^{9}$ mağdura iadesine veya suçun resmi makamlar tarafından öğrenilmesinden önce ihbarına ${ }^{10}$ bağlanmıştır. Hükümlerin çoğunda etkin pişmanlık sonucu cezai indirim öngörülürken, istisnai durumlarda cezaya hükmolunmayacağ ${ }^{11}$ ya da kamu davasının açılmayacağ ${ }^{12}$ şeklinde düzenleme yapılmıştır.

\section{SUÇA IŞTIRAK HALINDE ETKIN PIŞMANLIK}

TCK'da iştirak halinde işlenen suçlar bakımından etkin pişmanlık hükmünün nasıl tatbik edileceğini açıkça belirleyen bir hüküm bulunmamaktadır. Niteliksel bağlılık kuralının kapsamını belirleyen TCK md. 40/1 hükmüyle; sadece kusurluluğu etkileyen hallerin değil, şahsi cezasızlık sebepleri ve cezayı kaldıran şahsi sebeplerin, bu arada etkin pişmanlık hükümlerinin de suç ortaklarının sorumluluğu üzerinde etkili olmadığı, bu anlamda etkin pişmanlığın söz konusu olduğu bir suç tipinin iştirak halinde işlendiği hallerde, sadece etkin pişmanlık gösteren suç ortağının bundan yararlanacağı kabul

8 Örneğin, "Rüşvet alan kişinin, durum resmi makamlarca öğrenilmeden önce, rüşvet konusu şeyi soruşturmaya yetkili makamlara aynen teslim etmesi halinde, hakkında rüşvet suçundan dolayı cezaya hükmolunmaz." TCK md 254/1.

9 Örneğin, "Hırsızlık, mala zarar verme, güveni kötüye kullanma, dolandırıclık, hileli iflâs, taksirli iflâs (...) $)^{1}$ suçları tamamlandıktan sonra ve fakat bu nedenle hakkında kovușturma başlamadan önce, failin, azmettirenin veya yardım edenin bizzat pişmanlık göstererek mağdurun uğradığı zararı aynen geri verme veya tazmin suretiyle tamamen gidermesi halinde, verilecek cezanın üçte ikisine kadarı indirilir." TCK md 168/1.

10 Örneğin, "Uyuşturucu veya uyarıcı madde imal ve ticareti suçlarına iştirak etmiş olan kişi, resmi makamlar tarafından haber alınmadan önce, diğer suç ortaklarını ve uyuşturucu veya uyarıcı maddelerin saklandığı veya imal edildiği yerleri merciine haber verirse, verilen bilginin suç ortaklarının yakalanmasını veya uyuşturucu veya uyarıcı maddenin ele geçirilmesini sağlaması halinde, hakkında cezaya hükmolunmaz." TCK md 192/1.

11 Örneğin, "Sahte olarak para veya kıymetli damga üreten, ülkeye sokan, nakleden, muhafaza eden veya kabul eden kişi, bu para veya kıymetli damgaları tedavüle koymadan ve resmi makamlar tarafından haber alınmadan önce, diğer suç ortaklarını ve sahte olarak üretilen para veya kıymetli damgaların üretildiği veya saklandığı yerleri merciine haber verirse, verilen bilginin suç ortaklarının yakalanmasını ve sahte olarak üretilen para veya kıymetli damgaların ele geçirilmesini sağlaması halinde, hakkında cezaya hükmolunmaz." TCK md 201/1.

12 Örneğin, "Karşılıksız yararlanma suçunda, fail, azmettiren veya yardım edenin pişmanlık göstererek mağdurun, kamunun veya özel hukuk tüzel kişisinin uğradığı zararı, soruşturma tamamlanmadan önce tamamen tazmin etmesi halinde kamu davası açılmaz; zararın hüküm verilinceye kadar tamamen tazmin edilmesi halinde ise, verilecek ceza üçte birine kadar indirilir. " TCK md 168/5. 
edilmektedir. Bir başka deyişle iştirak halinde işlenen suçlarda, etkin pişmanlıktan sadece pişmanlık gösteren failin yararlanması esastır ${ }^{13}$.

Öte yandan mala karşı işlenen suçlarda ${ }^{14}$ suçun iştirak halinde işlenmesi durumunda, şeriklerden birisi veya birkaçının iade veya tazmin yükümlülüğünü yerine getirmesi halinde, diğer suç ortakları bu hususa karşı çıkmadıkları takdirde ${ }^{15}$ etkin pişmanlık hükümlerinden onlar da yararlanırlar. Etkin pişmanlık cezayı kaldıran ya da azaltan şahsi bir sebep olmakla birlikte, iştirak halinde işlenen suçlarda, fail veya suç ortaklarından birisinin geri verme veya tazmini gerçekleştirmesi, diğerlerinin bu maddeden yararlanma olanağını fiilen kaldırdığından buna engel olmak için pişmanlık gösteren diğer fail veya suç ortakları hakkında da TCK’nın 168. maddesi uygulanmalıdır ${ }^{16}$. Zira mağdurun zararı bir defa giderildiğinde, diğer fail ve şerikler yönünden giderilecek zarar kalmamıştır. Öte yandan onların tekrar aynı miktarda zararı gidermeye çalışmaları, mağdurun zararının çok üzerinde haksız bir menfaat elde etmesi anlamına gelir ki, bu da kabul edilemez. Ancak, etkin pişmanlık kurumunun düzenlenmesinde amaç failleri pişman olmaları halinde ödüllendirmek ve mağdurun kaybını mümkün olduğunca gidermektir. Bu durumda sırf bir failin pişmanlık göstermesi nedeniyle, pişmanlık göstermeyen suç ortaklarının cezalarında indirim yapmak hukuka ve hakkaniyete aykırı olacaktır. Bu nedenle, somut olayda pişmanlık göstermediği açıkça anlaşılan diğer suç ortakları

13 M. Emin Artuk, Ahmet Gökcen, M. Emin Alşahin ve Kerim Çakır, Ceza Hukuku Genel Hükümler, (15. Baskı, Adalet 2021) 672; Baki, (n 1), 49-50. Doktrinde Özen de, bizzat pişmanlı göstermek ifadesi çerçevesinde, her bir şerikin pişmanlık duyması ve bu duygu ile ödemeye katılmış olması gerektiği, zararın șeriklerden biri tarafından karşılanmasının bu fikra hükmünün amacını karşılamayacağı, hem pişmanlık hem de zararın karşılanmasında her şerikin katkısı olması gerektiği görüşündedir. Mustafa Özen, Öğreti ve Uygulama Işığında Ceza Hukuku Özel Hükümler Cilt II, (2. Baskı, Adalet 2021) 783-784. Nitekim Yargitay 15. Ceza Dairesinnin E.2018/4018 K.2019/4548, 30.4.2019 tarihli kararında; toplam kurum zararı üzerinden yapılan kısmi ödeme nedeniyle sanık hakkında etkin pişmanlık hükümlerinin uygulanıp uygulanmayacağının tartışılması gerektiği gerekçesiyle yerel mahkeme kararının bozulmasına karar verilmiştir. Yine Yargitay 2. Ceza Dairesi'nin E.2020/20408 K.2020/12630, 11.11.2020 tarihli kararında da; sanıklar tarafindan sonradan gerçekleştirilen bir ödeme olup olmadığı, zararın tamamının giderilip giderilmediği, zarar gideriminin hangi aşamada olduğu açıklığa kavuşturularak, kısmi ödeme konusunda muvafakat olup olmadığı sorularak sonuçlarına göre sanıklar hakkında 5237 sayılı TCK’nun 168. maddesinde düzenlenen etkin pişmanlık hükümlerinin değerlendirilmesi gerektiği gözetilmeden uygulama yapılması nedeniyle yerel mahkeme kararının bozulmasına karar verilmiştir. (Lexpera İçtihat Bilgi Bankası)

14 Malvarlığına karşı işlenen suçlarda etkin pişmanlık uygulaması için bkz. Mahmut Koca ve İlhan Üzülmez, Türk Ceza Hukuku Özel Hükümler, (7. Baskı, Adalet 2020) 669; Hırsızlık, yağma ve dolandırıcılık suçlarında etkin pişmanlık hükümlerinin uygulanması ve koşulları hakkında bkz. Artuk, Gökcen, Alşahin ve Çakır, (n 6) 584-585, 660, 693-695; Özen (n 13) 782-784.

15 Doktrinde, TCK md. 168 hükmünde "bizzat pişmanlik göstererek" ifadesi yer aldığından, faillerden birinin/birkaçının suçtan doğan zararı gidermesi durumunda, giderimi bilmesi ve rıza göstermesi yani tıpkı suçun birlikte işlenmesi gibi iade veya tazminin de iştirak halinde gerçekleştirilmesi şartıyla diğer fail/faillerin de etkin pişmanlık hükmünden yararlanacağı görüşü ileri sürülmektedir. Buna göre hükümde bizzat pişmanlık gösterilmesinden söz edildiği için zararın iştirakçilerden biri tarafından karşılanması, diğer kişilerin pişmanlık gösterip göstermediğinin araştırılmasına engel değildir; hatta bu konuda bir araştırmanın yapılması gerekir. Yargıtay, suç ortaklarından birinin yaptığı iade veya tazmine diğer iştirakçilerin karşı çıkmayarak giderimi kabullenmesini, iştirak halinde işlenen suçlarda bizzat pişmanlık gösterilmesinin ölçütü olarak kabul etmektedir. Mehmet Gödekli, 'Türk Ceza Öğretisi ve Uygulamasında Etkin Pişmanlık', (2017) 7 (29) Türkiye Adalet Akademisi Dergisi, 277, 347-348 <https://kutuphane.dogus.edu.tr/mvt/ pdf.php?pdf=0020438\&lng=0 $>$ Erişim Tarihi: 1 Eylül 2021.

16 Hüseyin Eker, 'Mala Karşı İş̧lenen Suçlarda Etkin Pişmanlık (5237 sayılı TCK’nın 168. maddesi)' (2012) (100) Türkiye Barolar Birliği Dergisi 363, 374. <http://tbbdergisi.barobirlik.org.tr/m2012.100.1192 363-388> Erişim Tarihi 1 Eylül 2021. 
hakkında, TCK 168 inci maddenin tatbik edilmemesi gerektiği görüşü de dile getirilmektedir ${ }^{17}$. Kanaatimizce iştirak halinde işlenen suçlarda etkin pişmanlığın, TCK çerçevesinde koşulları taşıyan suç ortakları açısından tatbiki yanında, bu hususa itiraz etmeyen ve pişmanlık gösterdiği anlaşılabilen şerikler açısından da cari olması gerektiği, zararın tazmini yükümlülügünün ise tüm şerikler tarafından yerine getirilmesinin aranmasına gerek olmadığı, esas olanın mağdurun uğradığ 1 zararın bir şekilde izalesi olduğu kural olarak kabul edilebilecek olmakla birlikte, özel kanunlarda yer alan etkin pişmanlık düzenlemelerinde suça ilişkin hususiyetler çerçevesinde farklı değerlendirme yapılması lüzumu da söz konusu olabilecektir. Özellikle çalışma konumuzu oluşturan suçların nitelikleri çerçevesinde, pişmanlığın sirayeti konusunun, suç tiplerinin kendine özgü durumları da dikkate alınarak değerlendirilmesinin önemli olduğu düşüncesindeyiz.

$\mathrm{Bu}$ çerçevede, SPK'da etkin pişmanlık kurumunun tatbikinin olanaklı olduğu işlem bazlı piyasa dolandırıcılığı ve örtülü kazanç aktarımı suçlarından özellikle piyasa dolandırıcılığı suçunun genellikle iştirak halinde işlendiği dikkate alındığında, etkin pişmanlık ve iştirak ilişkisinin, işbu çalışma konumuz açısından da ehemmiyet arz ettiği ve ayrıntılı bir şekilde analiz edilmesi gerektiği açıktır. Aşağıda her iki suç tipi açısından da etkin pişmanlık kurumu ile iştirak ilişkisi ayrı ayrı değerlendirilecektir.

\section{UZLAŞMA KURUMU ILE IRTIBATI}

5271 sayılı Ceza Muhakemesi Kanunu’nun ${ }^{18}$ (CMK) 253-255 maddeleri arasında düzenlenen uzlaşma; bağımsız ve objektif üçüncü bir kişinin, uyuşmazlı̆̆ın taraflarına, olayın özelliklerine göre şekillenecek çeşitli çözüm önerileri sunup, onların bu çözüm önerilerini müzakere etmesini ve sunulan çözüm önerilerinden birisi üzerinde anlaşmalarını hedefleyen bir alternatif uyuşmazlık çözüm yöntemi olarak tavsif edilebilir ${ }^{19}$. Bu çerçevede uzlaşma, şüpheli ile mağdur veya suçtan zarar gören kişinin uzlaştırılması girişimini ifade etmekte olup, tarafların uzlaşması halinde ya kovuşturmaya yer olmadığı kararı verilmekte ya da kamu davasının açılmasının ertelenmesine hükmedilmektedir ${ }^{20}$.

17 A. Caner Yenidünya, 'Malvarlığına Karşı Suçlarda Etkin Pişmanlık ve Uygulaması' <https://caneryenidunya.com/ malvarligina-karsi-suclarda-etkin-pismanlik/> Erişim Tarihi: 1 Eylül 2021. İștirak halinde ișlenen suçlarda, mağdurun suçtan doğan zararının tazminine yönelik olumlu bir girişimde bulunmayan ve katkı sağlamayan failler, diğer failin yararlandığı etkin pişmanlık hükmünden yararlanamaz. İsmail Turgut Kıldan, 'Malvarlığına Karşı İşlenen Suçlarda Etkin Pişmanlık Hükmünün Uygulanabilme Koşulları' (2012) 3 (8) Türkiye Adalet Akademisi Dergisi 115, 131. Yargıtay’ın konuya ilişkin örnek kararları için bkz. ibid 131'de yer alan 80, 81, 82 ve 83 nolu dipnotlar.

18 Ceza Muhakemesi Kanunu, Kanun Numarasi: 5271, Kabul tarihi: 4.12.2004, RG 17.12.2004/25673.

19 Kara Avrupası̉nda en basit şekliye uzlaşma, mağdur, iddia, savunma ve yargının belli menfaatler karşllığında anlaşarak muhakemeyi sona erdirmelerini ifade eden bir kavramdır. Nur Centel ve Hamide Zafer, Ceza Muhakemesi Hukuku, (20. Baskı, Beta 2021) 591. Uzlaştırma kavramı, uzlaştırmanın özellikleri, uzlaşmaya tabi olan ve olmayan suçlar, uzlaştırma süreci için Vahit Bıçak, Ceza Muhakemesi Hukuku, (4. Baskı, Seçkin 2018) 384-392; Feridun Yenisey ve Ayşe Nuhoğlu, Ceza Muhakemesi Hukuku, (9. Baskı, Seçkin 2021) 848-858. Uzlaştırmaya dair doktrindeki tanımlar ve yargı kararlarına yansıması konusunda bkz. Hazal Ertemür, Ceza Muhakemesi Hukukunda Alternatif Bir Çözüm Yolu Olarak Uzlaştırma, (Seçkin 2021) 29-35.

20 Uzlaştırmanın, ceza ilişkisini düşüren bir niteliği olduğu açıktır. Soruşturma evresinde uzlaşmanın gerçekleşmesi halinde savcı tarafından kovuşturmaya yer olmadığı, kovuşturma evresinde tarafların uzlaşması halinde mahkeme tarafından 
İlk olarak 2006 yılında 5560 sayılı Kanunla ${ }^{21}$ CMK’nın 253 üncü maddesinde yapılan değişiklikle, etkin pişmanlığın uygulanabildiği suçlarda uzlaşma kurumunun uygulanması imkânı ortadan kaldırılmıştır. Bunun gerekçesi, sanığın, lehine olan bir imkân olarak etkin pişmanlığı kullanmadığı takdirde uzlaşma yoluna da gitmeyeceği düşüncesidir. Bu gerekçe doktrinde, etkin pişmanlık hükümlerine yer verilen bazı suçlar uzlaştırmaya çok elverişli olmasına karşlık, bu suçlarda uzlaştırma yolunun kapatılmasının isabetli olmadığı gerekçesiyle eleştirilmiştir ${ }^{22}$. Müteakiben 2016 yılında 6763 sayılı Kanun ${ }^{23}$ ile değişiklik yapılarak, uzlaştırma, etkin pişmanlık hükümlerine yer verilen suçlar bakımından da uygulanabilir hale getirilmiştir ${ }^{24}$.

Uzlaşma ile etkin pişmanlık arasındaki farklar; uzlaşmanın temel amacının mağdurun zararının izalesi olmakla birlikte etkin pişmanlık öngörülen suçların tamamında mağdurun zararının oluşmaması, etkin pişmanlıkta mağdur ile suçtan zarar görenin bir araya gelmemesi ve son olarak etkin pişmanlıkta suç tamamlandıktan sonra failin iradi olarak neticeyi ortadan kaldırmaya yönelik davranışlar sergilemesi şeklinde ifade edilebilir.

CMK’nın 253 üncü maddesinde 7188 sayılı Kanun ${ }^{25}$ ile yapılan değişiklik ile aralarında TCK md. 155 'te yer alan güveni kötüye kullanma suçu da dâhil olmak üzere bazı suçlar uzlaştırma kapsamına alınmıştır. SPK md. 110 hükmü, güveni kötüye kullanma ve sahtecilik başlığı ile düzenlenmiş olup, TCK md. 155 hükmünde düzenlenen "güveni kötüye kullanma" suçunun sermaye piyasalarındaki görünümü mahiyetindedir ve adı geçen suçun nitelikli halini oluşturmaktadır.

Konumuz açısından değerlendirildiğinde, etkin pişmanlı̆̆ın uygulanabildiği SPK md. 110/1-b ve c hükümlerindeki örtülü kazanç aktarımı suçunun, uzlaştırma kapsamında olup olmadığı akla gelebilir. CMK md. 253/2 hükmünde, soruşturulması ve kovuşturulması şikâyete bağlı olanlar hariç olmak üzere; diğer kanunlarda yer alan suçlarla ilgili olarak uzlaştırma yoluna gidilebilmesi için, kanunda açık hüküm bulunması gerektiği hükme bağlanmıştır. SPK 110/1 maddesinin, ceza hükmü açısından TCK md. 155/2 hükmüne atıf yaptığı, güveni kötüye kullanmanın nitelikli hali olarak SPK'da özel düzenlemelere yer verilerek suç tasnif ve nitelemesi yapıldığı, dolayısıyla atılı suçun unsurları itibariyle SPK'da düzenlendiği, özel kanunlarda yer alan suçlar bakımından uzlaşma yoluna

düşme kararı verilecektir. (CMK m.253) Veli Özer Özbek, Koray Doğan ve Pınar Bacaksız, Türk Ceza Hukuku Genel Hükümler, (12. Baskı, Seçkin 2021) 773.

21 Çeşitli Kanunlarda Değişiklik Yapılmasına İlişkin Kanun, Kanun Numarası: 5560, Kabul tarihi: 6.12.2006, RG 19.12.2006/26381.

22 Mustafa Özbek, 'Ceza Muhakemesi Kanununda Yapılan Değişiklikler Çerçevesinde Mağdur Fail Uzlaştırmasının Usul ve Esasları' (2007) 56 (4) 123, 157. Örneğin, Türk Ceza Kanununun 168. maddesine göre, malvarlığına karşı suçlarda (hırsızlık, mala zarar verme, güveni kötüye kullanma, dolandırıcılık, hileli iflas, taksirli iflas ve karşılıksız yararlanma suçlarında) etkin pişmanlık özel olarak düzenlemiştir. Buna göre, Türk Ceza Kanununun 151. maddesinde yer alan ve soruşturulması ve kovuşturulması şikâyete bağlı olan mala zarar verme suçunda (TCK md 151,1) uzlaştırmaya başvurulamayacaktır.

23 Ceza Muhakemesi Kanunu İle Bazı Kanunlarda Değişiklik Yapılmasına Dair Kanun, Kanun Numarası: 6763, Kabul tarihi: 24.11.2016, RG 2.12.2016/29906.

24 24/11/2016 tarihli ve 6763 sayılı Kanunun 34 üncü maddesiyle, bu fikrada yer alan "etkin pişmanlık hükümlerine yer verilen suçlar ile" ibaresi madde metninden çıkarılmıştır.

25 Ceza Muhakemesi Kanunu İle Bazı Kanunlarda Değişiklik Yapılmasına Dair Kanun, Kanun Numarası: 6763, Kabul tarihi: 17.10.2019, RG 24.10.2019/30928. 
gidilebilmesi için özel bir düzenleme olması gerektiği, SPK'da ise böyle bir düzenleme olmadığı dikkate alındığında, SPK md. 110 hükmünde düzenlenen örtülü kazanç aktarımı suçu açısından uzlaşma kurumunun tatbikinin mümkün olmadığı kanaatindeyiz ${ }^{26}$.

\section{6362 SAYILI SERMAYE PIYASASI KANUNU'NDA ETKIN PIŞMANLIK}

Mülga 2499 sayılı Sermaye Piyasası Kanunu’nu yürürlükten kaldıran 6362 sayılı Kanun’un cezai hükümlere ilişkin önemli yeniliklerinden birisi de, işleme dayalı piyasa dolandırıcıllğ̆ (manipülasyon) ve örtülü kazanç aktarımı şeklinde teşekkül eden güveni kötüye kullanma suçları için etkin pişmanlık hükümlerine yer vermesidir. Kanun'da düzenlenen iki suç tipi için öngörülen etkin pişmanlık düzenlemeleri, SPK’nın 107 nci maddesi ile 110 uncu maddesinde yer almaktadır. Ödemenin yapılacağı aşama ile ilgili olarak benzer bir yaklaşım çerçevesinde düzenlenen etkin pişmanlık kurumuna ilişkin hükümlerde, her iki suç tipinin özellikleri göz önüne alınarak suç tipine özgü farklılıklar da bulunmaktadır.

\section{A. PIYASA DOLANDIRICILIĞI SUÇUNDA ETKIN PIŞMANLIK}

\section{GENEL OLARAK}

SPK'da yer verilen etkin pişmanlık hükümleri, TCK'da yer alan etkin pişmanlık hükümlerinden "yararlanma şartları" bakımından farklılık arz etmektedir. Örneğin TCK md. 168'de düzenlenen malvarlığına yönelik işlenen suçlar bakımından "mağdurun uğradığı zararın aynen veya tazmin suretiyle tamamen geri verilmesi” esas alınmış olmakla birlikte SPK md. 107/1 hükmünde düzenlenen işleme dayalı piyasa dolandırıcıl lğı suçunda zarara uğrayan kişiler belirlenebilir olmadığı gibi, bu suç tehlike suçu olması hasebiyle neticenin gerçekleşmesi şartı da bulunmadığından, zarara uğrayan bir kişi de bulunmayabilir. Dolayısıyla, SPK md. 107/3 ve md. 110/3 hükümlerinde, kanun koyucu TCK md. 168 hükmünden farklı olarak "mağdurun zararının tazmin edilmesi” yaklaşımı yerine, doğrudan Hazine’ye ödeme yapılması şartını getirmiştir. Nitekim, SPK’nın etkin pişmanlık hükmünün düzenlendiği madde gerekçesi incelendiğinde, kanun koyucunun temel amacının suçtan elde edilen menfaatin ekonomiye geri kazandırılması olduğu görülmektedir ${ }^{27}$. Yapılan ödeme, genel gerekçede belirtildiği üzere ilgililer hakkında suç duyurusu yapılmamasını değil, yapılan yargılama sonucunda cezaya hükmolunmamasını/cezada indirim yapılmasını sağlamaktadır. Madde gerekçesine göre,

26 Doktrinde Karacan tarafından, SPK md 106 ve devamında yer alan sermaye piyasası suçlarının tümü için yeni ve sermaye piyasasının özelliklerine, yasadaki suçların niteliği ile bu suçların zarar verdiği değerler ve mağdurları dikkate alan bir uzlaşma sistemine gereksinim olduğu, bu sistem sayesinde hem kurallara uyumun artırılabileceği hem de uzun, maliyetli ve çoğu kez yararı sınırlı yargılama yükünden kurtulma imkânı olacağı, uzlaşma miktarının ödenmesinden sonra çeşitli seçenekler olabileceği, uzlaşma kurumu nedeni ile artık soruşturma öncesi evrede etkin pişmanlığın uygulanmasına gerek olmayacağı görüşü serdedilmiştir. Ali İhsan Karacan, Sermaye Piyasası Hukuku Yazılar Cilt I, (Legal 2017) 648653.

27 Anılan gerekçe doktrinde, Hazine’ye yapılan ödemeyle, suçtan elde edilen menfaatin ekonomiye nasıl geri kazandırıldığı, suçla etkin mücadelenin hangi kapsamda gerçekleştirildiği ve etkin pişmanlıktaki mağdur odaklı yaklaşımın ne bakımdan sağlandığının belirsizliği nedeniyle eleştirilmektedir. Arzu Balan, Ekonomik Bir Suç Olarak Sermaye Piyasası Kanununda Düzenlenen İşleme Dayalı Piyasa Dolandırıcılı̆̆ı Suçu, (On İki Levha 2019) 245. 
etkin pişmanlık düzenlemesiyle, söz konusu suçla etkin ve caydırıcı bir şekilde mücadele etmenin yolları genişletilmiş olmaktadır²8.

\section{ETKIN PIŞMANLIĞIN UYGULANMA ŞARTLARI}

SPK’nın “Piyasa Dolandırıcılığı” başlıklı 107 nci maddesi;

"(1) Sermaye piyasası araçlarının fiyatlarına, fiyat değişimlerine, arz ve taleplerine ilişkin olarak yanlış veya yanıltıc izlenim uyandırmak amacıyla alım veya satım yapanlar, emir verenler, emir iptal edenler, emir değiştirenler veya hesap hareketleri gerçekleştirenler (Değişik ibare: 20/2/2020 tarihli ve 7222 sayıl Kanunun 37 inci maddesi ile) üç yıldan beş yıla kadar hapis ${ }^{29}$ ve beş bin günden on bin güne kadar adli para cezası ile cezalandırılırlar. Ancak, bu suçtan dolayı verilecek olan adli para cezasının miktarı, suçun işlenmesi ile elde edilen menfaatten az olamaz.

(3) Birinci fikrada tanımlanan suçu işleyen kişi pişmanlık göstererek, beşyüzbin Türk Lirasından az olmamak üzere, elde ettiği veya elde edilmesine sebep olduğu menfaatin iki katı miktarı kadar parayı, Hazineye;

a) Henüz soruşturma başlamadan önce ödediği takdirde, hakkında cezaya hükmolunmaz.

b) Soruşturma evresinde ödediği takdirde, verilecek ceza yarısı oranında indirilir.

c) Kovuşturma evresinde hüküm verilinceye kadar ödediği takdirde, verilecek ceza üçte biri oranında indirilir."

hükmünü haizdir.

Anılan hüküm çerçevesinde Sermaye Piyasası Kurulu (Kurul) tarafından yapılan denetim neticesinde, Kanunun 107/1 maddesi kapsamında işlem bazlı piyasa dolandırıcılı̆̆ı fiili işlendiğinin tespit edilmesi, anılan suçu işleyen kişi/lerin pişmanlık göstermesi/leri ve beş yüz bin TL'den az olmamak üzere elde edilen veya elde edilmesine sebep olduğu menfaatin iki katını Hazine’ye ödemesi/leri koşullarının kümülatif olarak gerçekleşmesi halinde, ödeme zamanına göre ya ilgili/ler hakkında cezasızlık ya da cezada indirim söz konusu olacaktır.

286362 sayılı Sermaye Piyasası Kanunu Gerekçeleri <https://mevzuat.spk.gov.tr/> Erişim Tarihi 30 Ağustos 2021.

29 Hükmün ilk halinde hapis cezasının alt sınırı iki yıl olarak belirlenmiş idi. CMK md 231 hükmü çerçevesinde iki yıl veya daha az hapis cezasının öngörüldüğü suçlarda diğer şartların da varlığı halinde hükmün açıklanmasının geri bırakılması (HAGB) kurumu tatbik kabiliyeti bulmakta idi. HAGB uygulamasında, sanık hakkında hükmolunan cezanın belli bir denetim süresi içerisinde sonuç doğurmaması, denetim süresi boyunca kasıtlı bir suç işlenmez ve yükümlülüklere uygun davranılırsa ceza kararının ortadan kaldırılması ve davanın düşmesine yol açması söz konusudur. Bu kapsamda SPK 107/1 hükmü açısından da faillerin de yüksek miktarda etkin pişmanlık ödemesi yapıp ceza almak yerine yargılanıp HAGB kurumundan istifade etmeyi tercih etmeleri söz konusu olmaktaydı. Nitekim, suçun cezasının alt sınırının üç yıla çıkması sonrası etkin pişmanlık başvurularında husule gelen artışın, etkin pişmanlık kurumunun işlerliğini ve etkinliğini artırdığı söylenebilir. 


\section{FAIL TARAFINDAN ELDE EDILEN BIR MENFAATIN BULUNMAMASI DURUMUNUN DEĞERLENDIRILMESi}

SPK’nın “Piyasa Dolandırıcılı̆̆ı” başlıklı 107 nci maddesinin gerekçesinde, piyasa dolandırıcılığında etkin pişmanlık hükmü öngörülerek bu suçla elde edilen ya da elde edilmesine sebep olunan menfaatin yeniden ekonomiye kazandırılmasının temin edildiği ifade edilmiştir. Bu nedenle, piyasa dolandırıcılığı suçunda failin suç nedeniyle hiç menfaat elde edemediği, hatta zarar ettiği durumlarda etkin pişmanlık hükümlerinin uygulanıp uygulanamayacağı hususunun da değerlendirilmesi önem arz etmektedir.

Doktrinde işlem bazlı piyasa dolandırıcılığı suçu bakımından özel olarak öngörülen "etkin pişmanlık" hükmü; yaptı̆̆ı işlemler neticesinde failin zarar etmesi halinde nasıl hareket edileceği ve etkin pişmanlık hükmünün, kesinleşmiş bir mahkûmiyet kararı olmaksızın, henüz soruşturma aşamasında "beş yüz bin liradan az olmamak" ya da "elde edilen menfaatin katları" gibi ceza mahiyetindeki hükümlerle ele alınmasının, faili ortaya koyduğu zarardan çok daha fazlasını yapmaya icbar etmesi nedeniyle etkin pişmanlıktan ziyade cezalandırma amacını daha çok yansıttığı gerekçeleriyle "suç ve ceza politikası" yönünden eleştirilmektedir ${ }^{30}$. Maddenin lafzı incelendiğinde "etkin pişmanlık" kurumundan yararlanma şartının, "menfaat elde etme” şartına bağlandığı anlamı çıkarılabilir. Failin işlemlerden zarar etmesi halinde "etkin pişmanlık" kurumundan yararlanamayacağı düşünülebilir ${ }^{31}$. Nitekim doktrinde de, etkin pişmanlık kurumunun, suçun maddi unsurunu teşkil etmeyen "menfaat" şartının elde edilmesi koşuluna bağlanmasının yerinde olmadığı, menfaat elde etmenin suçun maddi unsuru olmadığı, bu nedenle etkin pişmanlığın "menfaat”e bağlanmasının çelişkili olduğu, hükümde tutarsızlık bulunduğu, zira söz konusu suçun bir zarar suçu olarak değil, tehlike suçu olarak tanımlandığı, söz konusu suçun oluşabilmesi için, bir menfaat temin edilmiş olması gerekmediği yönünden eleştirilmektedir ${ }^{32}$. Yine gerekçe de dikkate alındığında kanun koyucunun amacının sadece menfaat elde eden veya edilmesini sağlayan failin etkin pişmanlıktan yararlanacağı, diğerlerinin faydalanamayacağı görüşü de ileri sürülmektedir ${ }^{33}$.

Her ne kadar madde gerekçesinde etkin pişmanlık hükmüyle amaçlananın suç nedeniyle elde edilen ya da elde edilmesine sebep olunan menfaatin ekonomiye kazandırılması olduğu ifade edilmekteyse de, etkin pişmanlık kurumunun, işlenen suçun cezasının azaltılmasını/ortadan kaldırılmasını sağlayan bir fonksiyonu olduğu dikkate alındığında, sadece menfaat elde edenlere bu indirim/ cezasızlık imkânının tanınmasının ceza adaletine aykırı sonuçlar doğuracağı, başka bir deyişle, suç konusu fiili menfaate çevirmeyi başaran failler ile başaramayanlar arasında, etkin pişmanlıktan

30 A. Caner Yenidünya, 'SPK’da Düzenlenen Suç ve Kabahatlere İlişkin Genel Prensipler' iç A. Caner Yenidünya, Mustafa Erkan ve Rayhan Asat (edr), İpek Yolu Canlanıyor-Türk Çin Hukuku Zirvesi (Adalet 2013) 90-91.

31 Seçil Coşkun, Sermaye Piyasası Hukukunda Piyasa Dolandırıcılığı Suçu (6362 Sayılı SPKn. Md. 107), (On İki Levha 2021) 176.

32 Can Canpolat, 'Uygulamaya Bakan Yönleriyle Piyasa Dolandırıcılığı Suçu' (2019) 5. Türk-Kore Ceza Hukuku Günleri, Karşılaştırmalı Hukukta Ekonomik Suçlar Sempozyumu 1, 20; İzzet Özgenç ve Gökhan Ölmez, 'Sermaye Piyasasında Güveni Korumaya Yönelik Yükümlülükler ve Ceza Hukuku Sorumluluğu' (2019) 5. Türk-Kore Ceza Hukuku Günleri, Karşılaştırmalı Hukukta Ekonomik Suçlar Sempozyumu 1, 7.

33 Buminhan Duman, Sermaye Piyasası Kanunu’nda Piyasa Dolandırıcılı̆̆ı (Manipülasyon) Suçu (Adalet 2020) $253-254$. 
yararlanarak cezadan kurtulma noktasında ayrım yapılmasının hakkaniyetle bağdaşmayacağı değerlendirilmektedir.

Kaldı ki, piyasa dolandırıcılığı bir tehlike suçu olup, bu suçtan menfaat elde edilmesi yalnızca adli para cezasının miktarının hesaplanmasında önem arz etmektedir. Dolayısıyla, etkin pişmanlık müessesesini yalnızca menfaat elde edilen piyasa dolandırıcılığı türlerine özgülemek, sistematik yorum ilkeleri ile de bağdaşmamaktadır. Şöyle ki, SPK md. 107/1 hükmünde fail tarafından menfaat elde edilip edilmemesine bakılmaksızın adli para cezası öngörülmüş, menfaat elde edilmesi yalnızca verilecek adli para cezasının alt sınırının belirlenmesinde esas alınmıştır. Maddenin ilk fikrasında menfaate ilişkin böyle bir düzenleme yer alırken, üçüncü fikrada etkin pişmanlık uygulamasının yalnızca menfaat elde edenler için getirildiğine ilişkin bir yorum yapılması madde sistematiğine de aykırılık teşkil edecektir.

Dolayısıyla, maddede failin beş yüz bin Türk Lirasından aşağı olmamak üzere elde ettiği ya da elde edilmesine sebep olduğu menfaatin iki katı tutarı Hazine’ye yatıracağı ifade edilmekle, etkin pişmanlıktan yararlanmak için menfaate bakılmaksızın alt sınırın beş yüz bin Türk Lirası olarak belirlendiği, yani, fail hiç menfaat elde edemese, hatta zarar etse dahi etkin pişmanlıktan yararlanmak için en az beş yüz bin Türk Lirasını Hazine’ye yatırması gerektiği kanaatindeyiz ${ }^{34}$.

\section{ETKIN PIŞMANLIK VE IŞTiRAK ILIŞKISI}

Suça iştirak halinde etkin pişmanlık meselesini, başka bir deyişle suç ortaklarından birinin etkin pişmanlık göstermesinin diğer ortaklara sirayet edip etmeyeceği meselesini piyasa dolandırıcılığ suçu bakımından tartışmak gerekir. Çünkü çoğunlukla grup halinde birden fazla kişinin birlikte hareket etmesi ile işlenebilen bir suç olma özelliği taşıyan (bu anlamda hemen tüm somut örneklerinde suça iştirakin söz konusu olduğu) piyasa dolandırıcılığı suçunda, SPKn. ile birlikte etkin pişmanlığın uygulanma imkanının doğmasıyla, bu mesele hemen her davada gündeme gelebilecektir. Etkin pişmanlık, TCK'daki etkin pişmanlığın kabul edildiği diğer suçlarda olduğu gibi şahsi bir cezasızlık ya da cezada indirim sebebidir. Maddede etkin pişmanlık göstermesi ve menfaat tutarının iki katını Hazine’ye ödemesi istenen kişi olarak "suçu işleyen kişi” deyimi kullanılmıştır. Madde lafzında, suçun birden fazla kişi ile işlenmesi halinde, sanıklardan birinin belirtilen tutarı yatırmasının etkin pişmanlık için yeterli olacağını yorumlamaya elverişli zımni bir ifade bulunmayıp, aksine kanun koyucu "suçu işleyen kişi”" şeklinde tekil bir ifade kullanarak, tutarın yatırılmış olmasına değil, ilgili kişinin tutarı yatırmış olmasına önem atfettiğinden, kanun koyucunun iradesinin, suç neticesinde menfaat elde etsin etmesin her sanığın, etkin pişmanlıktan yararlanmak istiyorsa, ayrı ayrı 500.000 TL’yi (menfaatin iki katı bu tutarı geçiyorsa o tutarı) Hazineye ödemesi gerektiği yönündedir ${ }^{35}$.

34 Benzer görüş için bkz. Gökçen Turan, 'Etkin Pişmanlık ve 6362 Sayılı Sermaye Piyasası Kanunu’nda Yeri' (2013) (13) Sermaye Piyasası Dergisi 106, 110. Yazar, piyasa dolandırıcılığı bir tehlike suçu olması nedeniyle, suçun oluşması için menfaat elde edilmiş olmasının şart olmadığı, bu bakımdan, sanıkların eylemleri sonucunda zarar ettiği piyasa dolandırıcılığı fiillerinde de, etkin pişmanlık için devlete ödenecek miktarın kanuni asgari sınır olan 500.000 TL olacağı görüşünü serdetmektedir.

İbid 111 . 
SPK'daki piyasa dolandırıcılığı suçu için yapılan düzenlemede, failin beşyüz bin Türk Lirasından aşağı olmamak üzere elde ettiği ya da elde edilmesine sebep olduğu menfaatin iki katı tutarı Hazine’ye yatıracağı ifade edilmekte olup, bu ödemede aslında suçun mağdurunun somut zararının fail tarafından tazmin edilmesi söz konusu değildir. Dolayısıyla, manipülasyon suçunda şeriklerden birinin parayı yatırması durumunda diğerlerinin etkin pişmanlık hükümlerinden faydalanma imkanı ortadan kalkmamaktadır, zira ortada yapılan ödemeyle tek bir kişi tarafından tazmin edilen somut bir zarar yoktur. Aksine, manipülasyona ilişkin düzenlemelerde, bu suçları işleyen kişilerin kanun koyucu tarafindan belirlenen bir miktar parayı devlete yatırarak ceza almamaları ya da cezalarında yapılacak bir indirimden yararlanmaları söz konusudur. Dolayısıyla, SPK'da iştirak halinde işlenen manipülasyon suçunda her bir failin Kanun'un ilgili maddelerinde belirtilen tutarda parayı Hazine’ye yatırmak suretiyle etkin pişmanlık hükümlerinden ayrı ayrı faydalanabileceği, bu parayı yatırmayan şerikin diğer şerikler yatırsa dahi etkin pişmanlıktan yararlanamayacağı şeklinde düzenleme yapıldığı kanaatindeyiz $^{36}$. Ayrıca bu konuda Kurul İlke Kararı ile belli esasların düzenlenmesi de, uygulamaya yön vermek açısından faydalı olabilecektir. Bu durumda Kurul tarafından yapılan incelemelerde hazırlanan raporlarda her bir fail tarafından elde edilen menfaatin ayrı ayrı hesaplanması önem arz etmektedir ${ }^{37}$.

Kurul uygulamasında da etkin pişmanlığın hukuki niteliği (şahsi cezasızlık sebebi) göz önünde bulundurularak, suç nedeniyle elde edilen menfaat miktarının belirlenebildiği durumda her bir fail bazında hesaplanan menfaat miktarının iki katının (asgari 500 bin TL olmak üzere) ödenmesi suretiyle, menfaat miktarının ayrıştırılamadığı durumda ${ }^{38}$ ise uygulamada yaşanılan özellikli durumlara ilişkin herhangi bir ayrıcalıklı usul belirlenmeksizin yine fail/şerik bazında ödeme yapılması ilkesi benimsenerek farazi olarak belirlenen miktarın (500.000) ödenmesi suretiyle şerikler etkin pişmanlık hükmünden yararlandırılmaktadır. Bir başka deyişle, her şerik elde ettiği menfaatin belirli olması halinde kendi gerçekleştirdiği işlemler nedeniyle elde ettiği menfaati, menfaatin şerik bazında belirli olmaması halinde ise farazi olarak belirlenen menfaat miktarını ayrı ayrı ödemekle yükümlü olup, birinin ödeme yapması diğerlerine sirayet etmemektedir ${ }^{39}$.

36 Benzer görüş için bkz. Balan, (n 20) 247. Yazar, hükümde, suça iştirak eden her fail için ayrı ayrı pişmanlık arandığı ve Hazine’ye de aynı minvalde ödeme yapılması gerektiği, suça iştirak eden her kişi, etkin pişmanlık için ödeme yaptığında, diğer şerikin hakkının ortadan kalkmadığı ve bir şerikin faydalanmasının diğer şeriklere sirayet etmediği görüşündedir.

37 Yildırım (n 5) 32.

38 Doktrinde Karacan, Kurul'un SPK md. 107/1'e aykırılık nedeniyle hazırladığı raporlarda kimlerin ne kadar menfaat elde ettiğini belirlemiş olması gerektiği ve bunu suç duyurularında belirtmesi, bu rakamı tespit etmeyip sadece fiil ve failleri belirlemiş ise o zaman sadece yasada belirtilen sabit rakamın ödenmesi ile yetinilmesi gerektiği düşüncesindedir. Karacan, (n 19) 644.

39 Yatırımcı grubunun birlikte hareket neticesinde gerçekleştirdiği piyasa dolandırıcılığı fiillerinde, kişi bazında menfaat ayrımının yapılamadığı ancak grup olarak elde edilen menfaatin çok yüksek olduğu vakalar açısından, her bir failin 500.000 TL tutarında Hazine’ye ödeme yapmak suretiyle etkin pişmanlıktan faydalanmasının da hakkaniyet ve adalet ilkesi ile bağdaşmayabileceği ileri sürülebilir. 


\section{SPK MD. IO7/3 HÜKMÜNDE 500.000 TL OLARAK BELIRTILEN TUTARIN YENIDEN DEĞERLEMEYE TABI OLUP OLMADIĞI}

SPK’nın çeşitli hükümlerinde, söz konusu hükümlerde belirtilen tutarların yeniden değerlemeye tabi olduğuna ilişkin düzenlemelere açıkça yer verilmiştir. Örneğin, SPK md. 84/5 hükmünde Yatırımcı Tazmin Merkezi tarafından yapılacak tazminin kapsamı düzenlenmiş olup, "Hak sahibi her bir yatırımcıya ödenecek azami tazmin tutarı yüz bin Türk Lirasıdır. Bu tutar her yıl ilan edilen yeniden değerleme katsayısı oranında artırılır.” hükmüne yer verilmiştir. Yine, SPK Geçici Madde 3’te Özel Fon tarafından, "31/12/2012 tarihine kadar bir alacak sahibine yapılacak ödeme tutar, 18.729 Türk Lirasını aşamaz. Bu tutar, 1/1/2013 tarihinden sonra her yıl ilan edilen yeniden değerleme katsayısı oranında artırılır." hükmü yer almaktadır.

Dolayısıyla, Kanunda düzenlenen belirli tutarların yeniden değerlemeye tabi tutulabilmesi için bu hususa yine Kanunda açıkça yer verilmesi ${ }^{40}$ gerektiği düşünülmektedir. Bu çerçevede, SPK md. 107/3 hükmünde beş yüz bin Türk Lirası olarak belirtilen tutarın Kanun'da bu yönde açık bir düzenleme bulunmaması nedeniyle yeniden değerlemeye tabi olmadığı, söz konusu tutarın uygulama için zaten yüksek bir tutar olarak belirlendiği, ilerleyen yıllarda yeniden değerleme ve güncelleme ihtiyacının hâsıl olması halinde, bu hususun kanun değişikliği ile gerçekleştirilmesi gerektiği kanaatindeyiz.

\section{B. ÖRTÜLÜ KAZANÇ AKTARIMI (GÜVENI KÖTÜYE KULLANMA) SUÇUNDA ETKIN PIŞMANLIK}

\section{GENEL OLARAK}

SPK içerisinde düzenlenen suçlardan biri de SPK md. 110 hükmünde düzenlenen "güveni kötüye kullanma ve sahtecilik" suçudur. Bu suç, TCK md. 155 hükmünde düzenlenen "güveni kötüye kullanma" suçunun sermaye piyasalarındaki görünümü olup, adı geçen suçun nitelikli halini oluşturmaktadır. Bu husus 6362 sayılı SPK md. 110/1 hükmünün ilk cümlesinde yer almaktadır. 2499 sayılı mülga SPK md. 47/I-A-5 ve md. 47/I-A-6 hükümlerinde düzenlenen güveni kötüye kullanma ve örtülü kazanç aktarımı fiilleri 6362 sayılı SPK’da tek bir maddede düzenlenmiş olup, 2499 sayılı mülga SPK md. 47/I-A-6’da “örtülü kazanç aktarımı” olarak düzenlenen suç ${ }^{41}, 6362$ sayılı SPK md.110/1 (b) ve (c) hükümlerinde yer almaktadır.

40 30/3/2005 tarihli ve 5326 sayılı Kabahatler Kanununun 17 nci maddesinin yedinci fikrasında idari para cezalarının her takvim yılı başından geçerli olmak üzere o yıl için 4/1/1961 tarihli ve 213 sayılı Vergi Usul Kanununun mükerrer 298 inci maddesi hükümleri uyarınca tespit ve ilân edilen yeniden değerleme oranında artırılmak suretiyle uygulanacağı ve bu şekilde yapılacak hesaplamalarda bir Türk Lirasının küsurunun dikkate alınmayacağı hükmü yer almaktadır. SPK'da yer alan idari para cezaları da mahiyeti itibariyle kabahat niteliğinde olduğundan, anılan hükme istinaden her yıl yeniden değerleme oranında artırılarak güncellenmektedir.

41 Bu suçun yaptırımı 2499 sayılı mülga SPK'da iki yıldan beş yıla kadar hapis ve beşbin günden onbin güne kadar adlî para cezası şeklinde düzenlenmişken, 6362 sayılı SPK'da bu fiilin nitelikli güveni kötüye kullanma suçunu oluşturduğu ifade edilerek, cezasının alt sınırı "üç yıl” olarak belirlenmiştir. Dolayısıyla bu suç için öngörülen ceza TCK md 155 ile birlikte değerlendirildiğinde, “üç yıldan yedi yıla kadar hapis ve üçbin güne kadar adlî para cezası” olarak değiștirilmiştir. 


\section{ETKIN PIŞMANLIĞIN UYGULANMA ESASLARI}

Etkin pişmanlığın uygulanıl usulü bakımından SPK md. 107 ile paralel bir düzenleme ${ }^{42}$ içeren SPK’nın “Güveni kötüye kullanma ve sahtecilik” başlıklı 110 uncu maddesinin 3 üncü fikrasında;

"(3) Birinci fikranın (b) ve (c) bentleri kapsamına giren güveni kötüye kullanma suçunu işleyen kişi, etkin pişmanlık göstererek 21 inci maddenin dördüncü fikrasında yer alan ödemenin yanı sıra bunun iki katı parayı Hazineye; a) Henüz soruşturma başlamadan önce ödediği takdirde, hakkında cezaya hükmolunmaz, b) Soruşturma evresinde ödediği takdirde, verilecek ceza yarısı oranında indirilir, c) Kovuşturma evresinde hüküm verilinceye kadar ödediği takdirde, verilecek ceza üçte biri oranında indirilir." düzenlemesine yer verilmiştir.

Dolayısıyla, suçun faili etkin pişmanlık hükümlerinden yararlanabilmek için öncelikle Kanun’un 21 inci maddesinde öngörülen örtülü kazanç olarak aktarılan tutarı yasal faizi ile birlikte malvarlığı

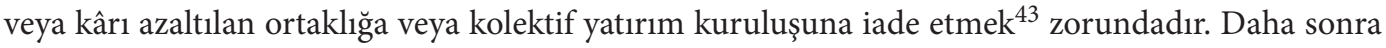
aktarılan tutarın iki katının soruşturma başlamadan önce Hazine’ye ödenmesi halinde bu suçtan dolayı cezaya hükmolunmaz. Bu tutarın soruşturma başladıktan sonra Hazine’ye ödenmesi halinde ise verilecek cezanın yarısı indirilir. Kovuşturma evresinde hüküm verilinceye kadar ödendiği takdirde ise, verilecek ceza üçte biri oranında indirilir.

Anılan düzenlemeye istinaden, örtülü kazanç aktarımı suçunda failin, etkin pişmanlık hükümlerinden yararlanabilmesinin ön koşulu, örtülü olarak aktarılan tutarı halka açık şirkete iade etmesidir. Anılan ödemeyi takiben, etkin pişmanlık gösterilerek örtülü kazanç aktarımı tutarının iki katının da Hazine’ye ödenmesi halinde hükümde öngörülen ödeme zamanına göre cezasızlık ya da cezada indirim uygulaması söz konusu olacaktır.

\section{ETKIN PIŞMANLIK VE IŞTIRAK ILIŞKISi}

SPK md. 110/3 hükmü kapsamında örtülü kazanç aktarımı suçunun iştirak halinde işlenmesi durumunda etkin pişmanlık uygulamasının ne şekilde tatbiki gerektiği de analiz edilmelidir. SPK'daki düzenlemede örtülü kazanç aktarımı suçunu işleyen failin etkin pişmanlıktan yararlanabilmesi için md. 21/4'teki ödemenin yanı sıra bunun iki katı tutarındaki parayı Hazineye ödemesi gerektiği belirtilmiştir.

Konuyu inceleyen Yıldırım’a göre, kanunun düzenlemesinden, örtülü kazanç aktarımının beş kişilik bir yönetim kurulu tarafından gerçekleştirildiği varsayımında, tek bir üyenin etkin pişmanlıktan faydalanmayı istemesi durumunda, bu kişinin öncelikle Şirket’in tüm zararını ödemesi gerektiği, daha sonra bu zararın iki katı tutarı Hazine’ye ödeyerek etkin pişmanlık hükümlerinden faydalanabileceği sonucuna ulaşıldığı, bu durumda Şirket’in zararı tek bir fail tarafından karşılandığı

42107 nci maddede sadece pişmanlık tabiri kullanılmasına karşın, 110 uncu maddede etkin pişmanlık deyimi tercih edilmiş olmakla birlikte, anılan husus esasa müteallik bir farklılık değildir.

43 Örtülü kazanıın iadesi kavramının detaylı ve mukayeseli incelenmesi için bkz Arif Duran, Örtülü Kazanç Aktarımı Yasağı (SerPK m. 21) (On İki Levha 2021) 321-329. 
için, bu failin diğer faillerle birlikte neden olduğu zarar dolayısıyla diğer faillere rücu hakkının doğacağı, birden fazla failin etkin pişmanlıktan yararlanmak istemesi halinde ise, bu faillerin hep birlikte Şirketin zararını karşılamaları gerektiği, etkin pişmanlıktan faydalanmayan başka failler varsa zararı karşılayan faillerin bunlara genel hükümler uyarınca rücu haklarının bulunduğu, bundan başka Şirketin toplam zararının iki katı tutarında parayı her birinin ayrı ayrı Hazineye ödemeleri gerektiği görüşü serdedilmiştir ${ }^{44}$. Bir başka görüşe göre ise, SPK md. 21/4'e göre hesaplanan meblağ ya da varlığın halka açık şirkete geri verilmesi gerektiği, bu iadenin öncelikle bundan yararlanan tarafından yapılması, onun tarafından yapılmaz ise şüphelilerin bundan müştereken ve müteselsilen sorumlu olacağı ifade edilmiştir ${ }^{45}$. Diğer bir görüşte ise, etkin pişmanlığa yönelik şartları kendisi açısından yerine getiren suç ortağının bundan faydalanabileceği, bir başka deyişle kendi payına düşen kısmın yerine getirilmesinin yeterli olduğu, zararın tamamının giderilmesinin gerekmediği kanaati serdedilmiştir ${ }^{46}$.

Öte yandan hükümde yer alan, şirket zararını karşılamak haricinde tespit edilen örtülü kazanç aktarımı tutarının iki katının Hazine’ye ayrıca ödenecek olması doktrinde, etkin pişmanlıktan faydalandırmaktan ziyade peşinen alınan bir para cezası izlenimi verdiği, bu ödemenin oldukça fahiş olup hükmün uygulama kabiliyetini azalttığı, TCK md. 168'deki gibi suçtan zarar görenin zararını gidermenin yeterli olması gerektiği ve bu düzenlemenin etkin pişmanlık kurumunun felsefesine aykırı olduğu yönlerinden de eleştirilmektedir ${ }^{47}$.

Doktrinde dermeyan edilen, hükmün uygulama kabiliyetinin güçlüğü yönündeki eleştirilere biz de iştirak ediyoruz. Nitekim uygulamada SPK md. 107/3 kapsamında işlem bazlı piyasa dolandırıcilığ 1 suçunda farklı vakalarda etkin pişmanlık başvuruları yapılmış olmakla birlikte SPK md. 110/3 hükmü kapsamında henüz etkin pişmanlık başvurusuna rastlanmamıştır. Bunda, etkin pişmanlıktan yararlanmak için öngörülen koşulların, suça ilişkin yaptırım ile mukayese edildiğinde orantılı olmaması ve son derece ağır olması önemli rol oynamaktadır. Özellikle örtülü kazanç aktarımı denetimlerinde tespit edilen halka açık şirket zararının son derece yüksek olduğu ${ }^{48}$ olaylarda,

44 Yıldırım (n 5) 32-33. Yine yazar, şirket zararını karşılayan fail dışında diğer faillerin etkin pişmanlıktan faydalanmak istemesi halinde, belirlenen tutarın iki katını Hazine’ye ödeyerek etkin pişmanlıktan faydalanabilecekleri, amaçsal yorum yapıldığında bu hakkın ellerinden alınmasının hakkaniyete uygun olmadığı, şirket zararını ödeyen failin rücu hakkının iç ilişkiyi ilgilendirdiği düşüncesindedir.

45 Karacan ( n 19) 644.

46 Ali Hakan Evik, 6362 Sayılı Sermaye Piyasası Kanunu’nda Düzenlenen (SerPK md 110/1-b ve c) Örtülü Kazanç Aktarımı Suçu (On İki Levha 2021) 148. Yine yazar Yargıtay 19. Ceza Dairesinin 14.3.2019 tarihli bir kararına atıf yaparak, örtülü kazanç aktarımında suça konu zararın sanıklardan tahsil edilip edilmediği araştırılmaksızın hüküm kurulmasını mahkemenin bozma nedeni olarak gördüğü belirtilmiştir. ibid 146.

47 Murat Sadak, Sermaye Piyasası Hukukunda Örtülü Kazanç Aktarımı Suçu, (Legal 2016) 116; Tekin Memiş ve Gökçen Turan, Sermaye Piyasası Hukuku, (5. Baskı, Seçkin 2020) 227; ibid 146.

48 Örneğin 8.2.2018 tarih ve 2018/6 sayılı SPK bülteninde yayınlanan suç duyurusu kararında halka açık şirketin 45.705.669 TL zarara uğratıldığı iddiasıyla altı kişi hakkında SPK md. 21 ve 110 hükümlerine istinaden suç duyurusunda bulunulmuştur. <https://www.spk.gov.tr/Bulten/Goster?year=2018\&no=6> Erişim tarihi 1.8.2021. Yine 23.5.2019 tarih ve 2019/26 sayılı SPK bülteninde yayınlanan suç duyurusu kararında, halka açık şirketin 3.728.799 TL zarara uğratıldığı iddiasıyla ilgililer hakkında SPK md. 110/c hükmü uyarınca suç duyurusunda bulunulması kararı kamuya duyurulmuştur. <https://www.spk.gov.tr/Bulten/Goster?year=2019\&no=26> Erişim tarihi: 1.9.2021. Yine 2.4.2020 tarih ve 2020/21 sayılı SPK bülteninde yayınlanan suç duyurusu kararında, ilişkili taraftan pay satın alınması işleminde halka açık şirketin 47.716.593 TL zarara uğratıldığı iddiasıyla ilgililer hakkında SPK’nın 110 uncu maddesine istinaden suç 
şirket zararını gidermek yanında, Kurul tarafından tespit edilen örtülü kazanç aktarımı tutarının iki katının Hazine’ye ödenmesi, ilgililer açısından son derece zorlayıcı ve haktan yararlanmak açısından caydırıcı olabilecektir. Öte yandan, örtülü kazanç aktarımı suçu nedeniyle yapılan yargılamada beraat kararı çıkması ihtimali de dikkate alındığında, anılan hüküm kapsamında etkin pişmanlık başvurusunda bulunmanın ve bunun sonuçlarından istifade etmenin teşvik edici olmaktan uzak olduğu kanaatindeyiz. Öte yandan, birden fazla kişi tarafından işlenen ve haklarında örtülü kazanç aktarımı suçundan yazılı başvuruda (suç duyurusu) bulunmaya karar verilen kişilerin etkin pişmanlıktan faydalanmaları noktasında örtülü kazanç aktarımı tutarının malvarlığı azaltılan halka açık şirkete ödenmesinden, ilişkili tarafa yapılan örtülü aktarımdan sorumluluk miktarlarının kişi bazında farklı şekilde tespit edildiği ayrıksı durumlar hariç olmak üzere genellikle ilgililerin müştereken ve müteselsilen sorumlu olmaları karşısında şirket zararının tek bir fail tarafından giderilmesinin yeterli olacağı, bu şekilde maksadın hâsıl olacağı, zararın müteaddit kereler giderilmesine lüzum bulunmadığı düşüncesindeyiz. Yine zararın tek bir kişi tarafından giderilmesi sonrası iç ilişkide rücu imkânı söz konusu olabilecektir. Diğer taraftan her ne kadar hükmün lafzında "suçu işleyen kişi” ifadesi kullanılsa da işlem bazlı piyasa dolandırıcılığı suçundan farklı olarak, etkin pişmanlıktan faydalanmak için örtülü kazanç aktarımı tutarının iki katının her bir fail tarafından ayrı ayrı Hazine’ye ödenmesi yerine, tek bir fail tarafından bu ödemenin yapılarak diğer faillere de pişmanlığın sirayet ettirilmesi ve iç ilişkide rücu imkânının bu ödeme için de uygulanması şeklinde yorum yapılmasının, hükmün tatbik kabiliyetini artırması açısından yerinde olacağı ancak nihai olarak hükümde yapılacak tadil ile kanunun on yıla yaklaşan yürürlük süresince hiç uygulanamayan SPK md. 110/3 hükmünün tatbik edilebilir şekilde tashih edilmesinin elzem olduğu kanaatindeyiz.

\section{ETKIN PIŞMANLIK ILE ILGILI UYGULAMA SORUNLARI}

\section{A. HÜKMÜN TATBIKI USULÜ}

Gerek piyasa dolandırıcılığı gerek örtülü kazanç aktarımı suçunun işlendiğinin Kurul tarafından tespit edilmesi ve Kurul Karar Organı tarafından yazılı başvuruda bulunulması kararı alınması sonras $^{49}$ ilgili şahıslarca etkin pişmanlıktan faydalanılmak istenmesi neticesinde ödemeye ilişkin belgelerin öngörülen süre içinde Kurul'a gönderilmesi ve anılan belgelerin suç duyurusu dilekçesi ile birlikte Kurul tarafından Savcılığa intikal ettirilmesi söz konusu olmaktadır. İlgililere verilen süre boyunca Kurul tarafından suç duyurusu yapılmamakta, verilen süre içinde ödemenin yapılıp yapılmadığı ve belgelerin Kurul’a iletilip iletilmediğinin kontrolü yapılarak etkin pişmanlıktan faydalanılması halinde ilgili ödeme belgeleriyle birlikte Savcılığa suç duyurusunda bulunulmakta ve konu Savcılığın takdirlerine sunulmaktadır.

duyurusunda bulunulmasına karar verilmiștir. <https://www.spk.gov.tr/Bulten/Goster?year=2020\&no=21> Erișim tarihi: 1.9.2021.

49 Kanunun 106-113 maddeleri arasından düzenlenen SPK’ya özgü suç tiplerinin unsurlarının somut olayda tahakkuk ettiğinin Kurul uzmanlarınca yapılan denetim çalışmaları neticesinde tespit edilmesi ve anılan tespitlerin Kurul Karar Organının kararı ile yazılı başvuruda bulunma ile neticelenmesi halinde Kurul tarafından ilgililer hakkında Cumhuriyet Başsavcılığı’na yazılı başvuruda bulunulmaktadır. Nitekim SPK’nın 115 inci maddesinde, Kanunda tanımlanan veya atıfta bulunulan suçlardan dolayı soruşturma yapılmasının, Kurul tarafından Cumhuriyet Başsavcılığı’na yazılı başvuruda bulunulmasına bağlı olduğu ve bu başvurunun muhakeme şartı niteliğinde bulunduğu açıcça düzenlenmiştir. 
Uygulamada Kurul Kararının Haftalık Bülten'de ilanının akabinde, Kurul kararından itibaren 15 gün içinde bültende belirtilen Hazine hesabına etkin pişmanlık ödemesinin yapılması ve yine aynı süre içinde ödemeye ilişkin belgelerin Kurula iletilmesi gerektiği ifade edilmektedir ${ }^{50}$. Sürenin başlama tarihinin Kurul karar tarihi değil, ilgililere gönderilecek etkin pişmanlık bildirim yazısının ${ }^{51}$ tebliğ tarihinden itibaren başlatılması da mümkün olmakla birlikte, tebliğ tarihinin esas alınmasının uygulamada yazının tebliğ edilip edilmediğinin takibi konusunda sorunlara neden olabileceği ileri sürülebilirse de, ilgililere bültende yayınlanan suç duyurusu kararlarını takip etmek külfeti yüklenmesi ve kanunen tanınan etkin pişmanlık hakkından istifade imkânlarının sınırlandırılması hukuken yerinde olmadığından, Kurul kararının ilgililere tebliği tarihinden itibaren 15 günlük süre verilmesi ve tebliğden itibaren 15 günlük sürenin sonuna kadar Kurul tarafından suç duyurusu yapılmadan beklenmesinin hakkaniyet açısından daha uygun olacağı kanaatindeyiz.

Öte yandan, ilgiliye tanınan süre içerisinde Kurul tarafından ilgililer hakkında suç duyurusunda bulunulmaksızın sürenin dolmasının beklenmesi de son derece önemlidir. Zira, bu sürenin bitimi beklenmeksizin konunun Savcilığa intikal ettirilmesi ilgililer açısından hak kayıplarına neden olabilecektir. Etkin pişmanlık ödemesinin soruşturma başlamadan önce yapılması cezasızlık sebebi olup, hükümde ilgililer hakkında cezaya hükmolunmaması öngörüldügünden, ilgililere verilen

50 27.5.2021 tarih ve 2021/26 sayılı Kurul Bülteni’nde, SPK'nın 110 uncu maddesine istinaden haklarında suç duyurusunda bulunulan kişiler için dipnotta etkin pişmanlıktan yararlanma prosedürü açıklanmıştır.

"SPKn'nun 110 uncu maddesi çerçevesinde hakkında suç duyurusu kararı alınan şahısların, SPKninun 110/3 hükmü uyarınca etkin pişmanlik hükümlerinden yararlanmak istemeleri durumunda, söz konusu hükümlerden yararlanabilmeleri için; SPKn’nun 21 inci maddesinin dördüncü fikrasında yer alan ödemenin yanı sira bunun iki katı tutarındaki parayı Kurul kararından itibaren 15 gün içinde; Hazine ve Maliye Bakanlı̆̆ının e-tahsilat hesabına (IBAN TR450.000.1001000.003.50154037, Vergi Kimlik Numarast:611.033.3534) "6362 sayll Kanunun 110/3 maddesi kapsaminda etkin pişmanlıktan yararlanma karşıllğı Hazineye ödemesi gereken tutar" açıklama notu ile ödemeleri ve aynı süre içinde Kurulumuza ilgili belgeleri iletmeleri gerekmektedir." $<$ https://www.spk.gov.tr/Bulten/Goster?year=2021\&no=26> Erişim Tarihi: 1 Eylül 2021. Yine 25.3.2021 tarih ve 2021/15 sayllı Kurul Bülteni’nde Sönmez Filament Sentetik İplik ve Elyaf Sanayi A.Ş. (SONME) pay piyasasında 20.06.2019-26.08.2019 döneminde gerçekleştirilen işlemlerde sorumluluğu bulunan aşağıdaki tabloda yer alan şahıslar hakkında 6362 sayılı Sermaye Piyasası Kanunu (SPKn)'nun 107 inci maddesinin birinci fikrası kapsamında işlem yapılmak üzere, 6362 sayılı SPKn’nun 115 inci maddesi uyarınca Cumhuriyet Başsavcıllğı’na suç duyurusunda bulunulmasına karar verildiği belirtilmiş ve kararın dipnotunda etkin pişmanlık prosedürü ilan edilmiştir. “6362 sayılı SPKn’nun 107/1 maddesi çerçevesinde hakkında suç duyurusu kararı alınan şahısların 6362 sayılı SPKn’nun 107/3 hükmü uyarınca etkin pişmanlık hükümlerinden yararlanabilmeleri için; beş yüz bin Türk Lirasından az olmamak üzere, elde ettiği veya elde edilmesine sebep olduğu menfaatin iki katı miktarı parayı Kurul kararından itibaren 15 gün içinde; Hazine ve Maliye Bakanlığı’nın e-tahsilat hesabına (IBAN TR450.000.1001000.003.50154037, Vergi Kimlik Numarasi:611.033.3534) "6362 sayılı Kanunun 107/3 maddesi kapsamında etkin pişmanlıktan yararlanma karşıllğı Hazineye ödenmesi gereken tutar" açıklama notu ile ödemesi ve aynı süre içinde Kurulumuza ilgili belgeleri iletmesi gerekmektedir." <https://www.spk.gov.tr/Bulten/Goster?year=2021\&no=15> Erișim Tarihi: 1 Eylül 2021.

51 İlgililere gönderilecek bildirim yazısında, suç duyurusuna dayanak kanun maddesi ile etkin pişmanlık hükümlerine, bu hükümlerden faydalanılmak isteniyorsa, belirtilen süre içerisinde ödenmesi gereken tutara ve bu tutarın nereye yatırılması gerektiğine ilişkin bilgiler ile söz konusu süre içinde anılan belgelerin SPK'ya iletilmesi gerektiği hususlarına ve bu hükümden yararlanılmasının sonuçlarına yer verilmesi uygun olacaktır. Karacan da, etkin pişmanlıktan faydalanma hakkı olan kişilere bu durumun bildirilmesi, hangi fiillerle yasayı ihlal ettiklerinin ayrıntılı ve değerlendirme yapıp karar almalarını sağlayacak nitelikte ve miktarda bilginin verilmesi, etkin pişmanlıktan yararlanmanın haklarında suç duyurusunda bulunmayı engellemeyebileceğinin de belirtilmesi gerektiği düşüncesindedir. Hakkın uygun bir biçimde kullanılmasının sağlanmamasının yargılama aşamasında ileri sürülebileceği gibi Anayasa Mahkemesine bireysel başvuruda bulunularak hak ihlali iddiasına konu olabileceği, uygun bir süreç izlenmemesinin ayrıca idari bir kusur olarak nitelenebileceği görüşündedir. Karacan ( n 19) 635-636. 
sürenin ikmalinin beklenmesi yerinde olacaktır. Etkin pişmanlık ödemesi yapılması halinde de, haklarında suç duyurusunda bulunulan kişiler hakkında yine de suç duyurusunda bulunulacak olmakla birlikte, hazırlanacak suç duyurusu dilekçesinde ilgili şahsın etkin pişmanlıktan yararlanma yönündeki isteği ile dilekçe ekinde gereken ödemeyi yapmış olduğuna ilişkin belgeler Savcıllğa intikal ettirilecek ve konu Savcılığın takdirine bırakılacaktır.

\section{B. SORUŞTURMA ÖNCESI ETKIN PIŞMANLIK HALINDE SUÇ DUYURUSU YAPILMASI VE SAVCININ DAVA AÇMASI KONUSUNDAKI TARTIŞMALAR}

SPK’nın etkin pişmanlığa ilişkin hükümlerinin uygulama alanının belirlenebilmesi için soruşturma ve kovuşturma evrelerinin ne zaman başlayıp sona erdiğinin ortaya konması önem arz etmektedir. Zira, Kanun'da yer alan düzenlemelerde soruşturma öncesi, soruşturma ve kovuşturma aşamaları bakımından cezalarda farklı oranlarda indirim öngörülmektedir. CMK’nın "Tanımlar" başlıklı 2 nci maddesinin (e) fikrasında soruşturmanın, "kanuna göre yetkili mercilerce suç şüphesinin öğrenilmesinden iddianamenin kabulüne kadar geçen evreyi" ifade ettiği belirtilmiştir. Dolayısıyla, soruşturma evresinin, kural olarak Cumhuriyet Savcısının, bazı ayrıksı hallerde de, soruşturma yapmaya yetkili diğer yetkili makamların suç şüphesini öğrenmesiyle başlayacağı ve iddianamenin kabulü ile hitama ereceği açıktır.

6362 sayılı SPK'daki etkin pişmanlık düzenlemelerinde soruşturma öncesinde fail tarafından Hazine’ye ödeme yapıldığı takdirde fail hakkında "cezaya hükmolunmayacağı" düzenlemesine yer verilmiştir. Anılan hükümlerde "dava açılmaz" ifadesi yerine "cezaya hükmolunmaz" ifadesi kullanıldığı için, soruşturma öncesinde gösterilen etkin pişmanlık hallerinde Cumhuriyet Savcısı tarafından kamu davası açılma zorunluluğunun bulunup bulunmadığı hususunun da değerlendirilmesi gerekmektedir.

İlk olarak, hükmün lafzı ve gerekçesi dikkate alındığında, etkin pişmanlık hükümlerinden yararlanmak amacıyla, hükümde belirtilen miktarın soruşturma başlamadan önce Hazine’ye ödenmesi fail(ler) hakkında Kurul tarafından yazılı başvuruda bulunulmasına engel teşkil etmeyecektir. Zira hükümde "soruşturmaya başlanmaz" ifadesi kullanılmamış, "cezaya hükmolunmaz" ifadesi tercih edilmiştir. Bu çerçevede, Kurul tarafından yapılan denetim faaliyetleri neticesinde işlem bazlı piyasa dolandırıcılığı ve örtülü kazanç aktarımı suçunun unsurlarının bulunduğu tespit edildiği takdirde, faillere yapılacak bildirim çerçevesinde, henüz Kurul tarafından yazılı başvuru yapılmadan, failler tarafından etkin pişmanlık hükümlerinden istifade edilmek suretiyle hükümde belirtilen tutarın Hazine’ye ödenmesi durumunda da Kurul tarafından yazılı başvuruda bulunulacağı, ancak ödeme yapılması nedeniyle Savcılık ve Mahkeme tarafından Kanun’un 107/3 ve 110/3 hükümleri dikkate alınarak gerekli kararlar verileceği ileri sürülebilir ${ }^{52}$.

52 Ahmet Tok, Sermaye Piyasası Kurulunun Halka Açık Şirketleri Denetlemesi (İksad 2021), 436-437. Soruşturma öncesi aşamada şüpheliler etkin pişmanlıktan faydalanmış ve md. 107/3 ve 110/3 uyarınca cezanın kaldırılmasını gerektiren şahsi bir neden ortaya çıkmış ise savcı, bu kişilerin hepsi veya bazıları hakkında takipsizlik kararı verebilir. Ya da hiçbiri hakkında takipsizlik kararı vermeyerek hepsini iddianameye dâhil edebilir ve onlar hakkında cezanın kaldırılmasını gerektiren şahsi bir nedenin varlığını belirtebilir. Soruşturma aşaması öncesinde etkin pişmanlıktan faydalanma, açılacak bir davada sanık olmamayı garanti etmez ancak bu yargılama sonunda cezalandırılmamayı sağlar. ibid 633-634. 
Kamu davası açmada takdir yetkisi başlıklı CMK’nın 171 inci maddesinde konu, "Cezayı kaldıran şahsî sebep olarak etkin pişmanlık hükümlerinin uygulanmasını gerektiren koşulların ya da şahsî cezasızlık sebebinin varlığı halinde, Cumhuriyet savcısı kovuşturmaya yer olmadığı kararı verebilir." şeklinde düzenlenmiştir. Bu çerçevede Cumhuriyet Savcısı soruşturma konusu fiili değerlendirerek, cezayı kaldıran etkin pişmanlık ve şahsi cezasızlık sebeplerinin varlığına kanaat getirir ise, iddianame düzenleyip düzenlememe konusunda takdir yetkisine sahiptir. Ayrıca, Cumhuriyet Savcısı́nın bu konuda kullanacağı takdir yetkisine karşı herhangi bir kanun yolu da öngörülmemiştir ${ }^{53}$. Anılan maddenin Cumhuriyet Savcısı'na verdiği yetki tartışmalı olmakla birlikte ${ }^{54}$, hükmün lafzından, kanunun dava açıp açmama konusunda takdir yetkisi tanıdığı sonucuna ulaşılmaktadır. Bu çerçevede Cumhuriyet Savcısının durumu değerlendirerek ya dava açacağı ya da takdir yetkisini kovuşturmaya yer olmadığı kararı verme yönünde kullanabileceği de söylenebilir.

SPK md. 107/3 ve 110/3 hükümleri ile CMK md. 171 birlikte değerlendirildiğinde, piyasa dolandırıcılığı ve örtülü kazanç aktarımı suçları bakımından etkin pişmanlık durumu varsa faillerin kanunda öngörülen tutarları ödemiş olmaları yeterli olacak ve Savcı’nın bu durumda dava açma yönünde takdir hakkını kullanması gereken bir durum söz konusu olmayacaktır. Başka bir deyişle, Savcı'nın yapacağı değerlendirme yalnızca fail tarafından etkin pişmanlık hükümlerinin uygulanması için gerekli tutarların ödenip ödenmediği yönünde olacaktır. Bu tutarlar fail tarafından ödenmişse CMK md. 171'de belirtilen etkin pişmanlık hükümlerinin uygulanmasını gerektiren koşulların varlığı gerçekleşmiş olacağından, Savcı'nın dava açma konusunda artık takdir yetkisini kullanmasına gerek olmadığı, "kovuşturmaya yer olmadığı kararı” vermesi gerektiği söylenebilir 55 .

Kanun hükmünde yer alan “cezaya hükmolunmaz” ifadesinin, CMK md. 171/1'de yer alan ve savciya takdir hakkı tanıyan düzenleme ile çelişki arz ettiği açıktır. Savcı tarafından verilen kovuşturmaya yer olmadığı kararı hüküm ${ }^{56}$ olarak nitelendirilemeyeceğinden, soruşturma öncesi etkin pişmanlık hallerinde de savcının iddianame düzenleyerek dava açması ${ }^{57}$ ve şüphelinin etkin pişmanlıktan faydalandığını belirterek gerekli hükmün tesisini mahkemeden talep etmesi yerinde olacaktır.

53 Fatih Birtek, 'Cumhuriyet Savcısı'nın Delilleri ve Fiili Takdir Yetkisi' (2013) 19 (2), Marmara Üniversitesi Hukuk Fakültesi Hukuk Araştırmaları Dergisi (Prof. Dr. Nur Centel’e Armağan) 953, 982.

54 Cumhuriyet Savcısı öncelikle fiili suçun unsurları yönünden değerlendirerek hangi kanun maddesi kapsamında olduğuna karar verdikten sonra bu tavsif çerçevesinde cezayı kaldıran şahsi sebep olarak etkin pişmanlık hükümlerinin ya da şahsi cezasızlık sebeplerinin uygulanıp uygulanmayacağını takdir edecektir. Feyzioğlu’na göre bu hallerde tersine bir bağlı yetki söz konusu olup, Cumhuriyet Savcısı kamu davası açamayacaktır. Metin Feyzioğlu, 'Ceza Muhakemesi Kanunu’na Göre İddianamenin Hazırlanması ve Kabulüne İlişkin Bazı Düşünceler’ (2006) 1 (1) Ceza Hukuku Dergisi 31, 34. Özen ise, CMK md. 223/4 hükmünden hareketle, bu durumlarda Cumhuriyet Savcısı'nın takdir yetkisini "dava açmama” yönünde kullanması gerektiği görüşünü serdetmektedir. Mustafa Özen, 'Kamu Davası Açma Konusunda Benimsenen İlkeler, Cumhuriyet Savcısının Takdir Yetkisi ve İddianamenin İadesi' (2009) 67 (3) 17, 27.

55 Yıldırım (n 5) 30-31; Doktrinde, soruşturma öncesi etkin pişmanlık halinde Kurulun yazılı başvuru yapması gerektiği, Savcının, başka bir suç yoksa CMK md 171/1 gereği takdir yetkisini kullanarak doğrudan kovuşturmaya yer olmadığı kararı verebileceği, bu karara karşı Kurul açısından da CMK 173/5 gereği itiraz yolunun kapalı olduğu görüşü ileri sürülmektedir. Duman (n 25) 258-259.

56 CMK md 223/1'de; beraat, ceza verilmesine yer olmadığı, mahkûmiyet, güvenlik tedbirine hükmedilmesi, davanın reddi ve düşmesi kararının hüküm olduğu belirtilmiştir.

57 Savcılık tarafından dava açılması yerine takipsizlik kararı verilmesi halinde SPK tarafından karara itiraz edilmeden kararın kesinleşmesi de sağlanabilir. 
Mahkeme tarafından yapılan yargılamada, etkin pişmanlık gibi cezayı kaldıran şahsi bir nedenin varlığı halinde kişinin sadece cezai sorumluluğuna gidilemeyeceği, ancak işlenen fiilin suç olma özelliğini sürdüreceği dikkate alınarak, kişi hakkında verilmesi gereken karar "beraat" kararı

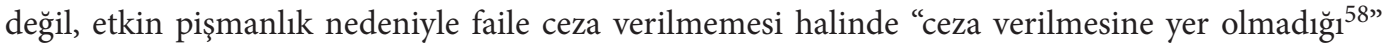
kararidir ${ }^{59}$.

Kurul uygulamasında da, soruşturma öncesi etkin pişmanlık hükümlerinden yararlanılmışsa ve ödenmesi gereken tutarlar ödenip belgeler Kurula süresinde ibraz edilmişse, yazılı başvuruda bulunulurken ${ }^{60}$, yazılı başvuruya konu suç ile ilgili olarak SPK md. 107/3 hükmü kapsamında etkin pişmanlık başvurusunda bulunulduğu ve etkin pişmanlık hükümleri uyarınca ödenmesi gereken 500.000 TL’nin (menfaatin iki katı daha yüksekse anılan tutarın) Kurul tarafından belirtilen hesaba ödendiği, bahse konu ödemeye ilişkin dekontun bir örneğinin yazılı başvuru ekinde Başsavcılığa sunulduğu belirtilerek, ilgili şahsın Kanun'da etkin pişmanlıktan faydalanabilmek için gerekli şartları yerine getirdiğinin de göz önünde bulundurulması ve Başsavcılık tarafından gereğinin yapılması talep edilmektedir. Yazılı başvuru dilekçesinde ödemeye ilişkin belgelerin Başsavcılığa ibraz edilmesi sonrası Başsavcılık tarafından tanzim edilen iddianamede, etkin pişmanlık başvurusunda bulunan ve gerekli koşulları taşıyan kişiler hakkında SPK’ya istinaden ceza verilmesine yer olmadı̆̆ı kararı verilmesi talebiyle konu Mahkemeye bırakılmış ve etkin pişmanlık nedeniyle kovuşturmaya yer olmadığı (takipsizlik) kararı verilmemiştir.

Son olarak belirtmek gerekir ki, yapılacak kanun değişikliğinde, soruşturma öncesi etkin pişmanlık durumları için "cezaya hükmolunmaz" ifadesi yerine "dava açılmaz" ifadesinin tercih edilmesinin, müessesenin felsefesi ve haktan yararlanan kişilerin menfaati açısından daha uygun olacağ kanaatindeyiz.

\section{FAIL TARAFINDAN HAZINEYE ÖDEME YAPILMASININ YERINDELIĞi}

Etkin pişmanlık hükümleri, genel olarak mağduriyetin giderilmesi amacıyla tesis edilen bir müessese olarak öngörülmesine rağmen, işlem bazlı piyasa dolandırıcılı̆̆ı işlemlerinde genellikle belirli bir

58 CMK 223/4’te, işlenen fiilin suç olma özelliğini devam ettirmesine rağmen; a) Etkin pişmanlık, b) Şahsî cezasızlık sebebinin varlığı, c) Karşılıklı hakaret, d) İşlenen fiilin haksızlık içeriğinin azlı̆̆ı, dolayısıyla, faile ceza verilmemesi hallerinde, ceza verilmesine yer olmadığı kararı verileceği hükme bağlanmıştır.

59 Kurşun (n 2) 151-152; İsmail Deniz, Ceza Muhakemesinde Hüküm, (Seçkin 2014) 115-116; Elif Bekar, 'Ceza Muhakemesinde Hüküm Çeşitleri (CMK m. 223’ (2017) LXXV (1) İstanbul Üniversitesi Hukuk Fakültesi Mecmuası 15, 30. 5352 sayılı Adli Sicil Kanunu'nun 4/1-g hükmüne göre etkin pişmanlık dolayısıyla verilen ceza verilmesine yer olmadığına dair hüküm adli sicile kaydedilecektir. Ahmet Gökcen, Murat Balcı, M. Emin Alşahin ve Kerim Çakır, Ceza Muhakemesi Hukuku, (5. Baskı, Adalet 2021) 632-633.

60 Kurul tarafından suç duyurusu kararı alınması halinde anılan karar Kurul Haftalık Bülteni’nde ilan edilerek kamuoyuna duyurulmaktadır. Haklarında suç duyurusunda bulunulan kişiler tarafından soruşturma öncesinde etkin pişmanlık gösterildiği durumlarda dahi Kurul tarafından suç duyurusunda bulunularak durumun Savcilığa intikal ettirilmesi, etkin pişmanlıktan faydalanmanın amacı ile de bağdaşmamaktadır. Zira adının suç duyurusuna karışması suretiyle etkin pişmanlıktan yararlanan kişilerin itibarı olumsuz etkilenmeye devam edebilecektir. Bir başka deyişle kanunun öngördüğü tutarı yatırmaları itibarlarının korunmasını temin edemeyecektir. Bu çerçevede, kanun değişikliği önerimiz yanında, etkin pişmanlıktan faydalanan kişilerin isim ve TC. kimlik numaralarının Kurul Bülteni’nde yapılacak ilanda karartılmasının yerinde olacağı kanaatindeyiz. 
mağdur bulunmamaktadır. İşlem bazlı piyasa dolandırıcılığı suçunda mağdurun tespitinin güç olması nedeniyle ${ }^{61}$ failin elde ettiği menfaatin iki katı kadar tutarın mağdura değil, Hazine’ye ödenmesi söz konusudur. Dolayısıyla, işlem bazlı piyasa dolandırıcılığı fiilinden zarar gören yatırımcıların zararını aynen giderme veya tazmin etme sistemine yönelik bir düzenleme yapılmamış ve failin doğrudan Hazine’ye ödeme yapması öngörülmüştür.

SPK'da etkin pişmanlık hükümleri öngörülen işlem bazlı piyasa dolandırıcılığı ve örtülü kazanç aktarımı suçları ekonomik kayba neden olan suçlar olmaları sebebiyle TCK'daki mala karşı işlenen suçlarla yapı itibariyle benzerlik göstermektedir. Ancak her iki kanundaki etkin pişmanlık hükümleri değerlendirildiğinde, failin etkin pişmanlıktan faydalanabilmesi için göstereceği davranışların farklı biçimde düzenlendiği görülmektedir. TCK md. 168'de mala karşı işlenen suçlarda etkin pişmanlık hükümlerinin uygulanabilmesi için mağdurun zararının aynen geri verme veya tazmin suretiyle giderilmesi, SPK'daki düzenlemelerdeyse piyasa dolandırıcılığında sadece Hazine’ye, örtülü kazanç aktarımı suçunda ise hem SPK md. 21/4 uyarınca mağdur Şirket’e hem de Hazineye ödeme yapılması şartı aranmaktadır. Öte yandan piyasa dolandırıcılığı suçunda, suçun mağdurlarının tespitinin güç olması nedeniyle fail tarafından aynen geri verme veya tazmin suretiyle bu kişilerin zararının giderilmesinin mümkün olmaması nedeniyle SPK'da TCK'dakine benzer bir düzenleme yapılması mümkün görünmemektedir ${ }^{62}$.

Öte yandan, yatırımcıların, ilgili pay piyasasında faillerin gerçekleştirdiği manipülatif işlemler nedeniyle zarara uğradığını Kurul'a bildirmesi halinde, yatırımcıların zararının tazmin edileceği bir mekanizma oluşturulması da mümkün olabilir. Özellikle piyasa dolandırıcılığı suçunda yatırımcıların ilgili pay piyasasında uğradıkları zarar ile manipülatif işlemler arasında illiyet bağının tesisi ve zarar miktarının tespiti kolay olmasa da, SPK md. 107/3 hükmünde değişiklik yapılarak, etkin pişmanlık hükümleri kapsamında faillerin/şeriklerin suçtan dolayı elde ettikleri menfaatin iki katının Hazine’ye yatırılması yerine, Amerika Birleşik Devletleri’nde (ABD) olduğu gibi ${ }^{63}$ yatırımcı

61 SPK'nın amacı doğrultusunda yatırımcıların korunması ve piyasaya güven ilkelerine dayanan sermaye piyasalarında piyasa bozucu eylemlere vücut veren işlemlerin belirlenmesi ve önlenmesi gerekmekte olup, pay fiyatlarının yapay sebeplerle artırılıp düşürülmesi ilk olarak milli ekonomiye, ikinci olarak Borsa’da alım satım yapan kişilerin mali menfaatlerine zarar verir. İşte bu çifte menfaati korumak, Kurulun amaçları arasındadır. İşlem bazlı piyasa dolandırıcılığında korunan hukuki menfaatin milli ekonomi olması nedeniyle geniş anlamda mağdurun devlet ve toplum, dar anlamda ise yatırımcı olması nedeniyle, mağduru belirsiz suç olarak kabul edilmekle birlikte, piyasa dolandırıcılığı suçunun mağdurlarının Kurul tarafından tespit edilebileceği de ileri sürülebilir. Zira borsada gerçekleştirilen işlemlerin, hem aracı kurum nezdinde hem de sermaye piyasası aracına ilişkin işlem emrinin verildiği hesap numarası ve yatırımcı bazında izlenmesi mümkündür. Ancak piyasa dolandırıcılığı suçunda aynı zamanda yatırımcıların yanıltılması ve piyasanın bozulması nedeniyle müstakbel yatırımcıların da piyasaya olan güveni zedeleneceğinden geniş anlamda onların da zarara uğratıldığından bahsedilebilir.

62 Yildirım (n 5) 35.

63 ABD'de piyasa dolandırıcılığı suçundan zarar gören yatırımcıların tazminine (Fair Fund) ve bu suçtan menfaat sağlayan failin elde ettiği kazancın iadesine (disgorgement) yönelik özel bir mekanizma oluşturulmuştur. Sarbanes-Oxley Kanunu md. 308-(a) hükmü SEC’ye, tesis ettiği idari para cezalarını, sermaye piyasası suçlarından zarar görmüş yatırımcıların tazmini için oluşturulacak fona ekleyebilme yetkisi vermiștir. Bu para cezalarının fona eklenme yetkisi SEC'nin takdirinde olup sermaye piyasası düzenlemelerine aykırı fiiller nedeniyle arar gören yatırımcıların tazmin edilmesi amacıyla failin elde ettiği menfaatin iadesinden ve "para cezalarından oluşan" "Yatırımcıları Tazmin Fonu" (Fair Fund) aracılığılla yatırımcılar tazmin edilmektedir.

Sarbanes-Oxley Act of 2002, Pub. L. No. 107-204, 116 Stat. 745 (codified as amended in scattered sections of 15, 18 
koruma fonuna benzer bir fonun kurulmasının, Kurul tarafindan idare ve temsil olunan Yatırımcı Tazmin Merkezi nezdinde ayrı bir hesapta etkin pişmanlık hükmü kapsamında ödenen paraların toplanarak, zarar eden yatırımciların zararlarının kısmen veya tamamen tazmin edilmesinin uygun olacağı değerlendirilmektedir ${ }^{64}$.

\section{SONUÇ}

Etkin pişmanlık kurumu TCK’da bazı suçlar açısından öngörülmüş iken SPK'da yalnızca işlem bazlı piyasa dolandırıcılı̆̆ı ve örtülü kazanç aktarımı suçlarında uygulama alanı bulacak şekilde düzenlenmiştir. TCK ile SPK'daki etkin pişmanlık hükümleri mukayese edildiğinde, SPK'daki suçlarla ilgili olarak düzenleyici ve denetleyici otorite sıfatiyla kanunen verilen yetkiye istinaden Kurul tarafından denetim yapıldığı ve bunun sonucunda ulaşılan tespitlerin SPK md. 115 uyarınca Kurul tarafından Savcıllğa intikal ettirildiği, etkin pişmanlığın Kurul’un denetim sonrası aldığı suç duyurusu kararıyla uygulama alanı bulduğu, bunun dışında iade ve ödemenin özellikle piyasa dolandırıcılığında mağdura değil, Hazine’ye yapıldığı hususları ile sermaye piyasasının işleyişi ve özellikleri göz önünde bulundurulduğunda, SPK'daki etkin pişmanlık uygulamasının kendine özgü olduğu ve bu nedenle de işleyiş esaslarının TCK'dan farklı şekilde belirlendiği görülmektedir.

SPK'daki etkin pişmanlığa ilişkin düzenlemede Hazine’ye yapılacak ödemenin soruşturma başlamadan önce yapılması halinde fail hakkında cezaya hükmolunmayacağı düzenlenmekle birlikte, Kanun'un genel gerekçesinde bu durumda Kurul tarafından suç duyurusunda bulunulması gerektiği açıkça ifade edilmiştir. Etkin pişmanlıktan faydalanmak isteyen fail ile bu haktan istifade etmeyen kişilerin tamamı hakkında suç duyurusu yapılması ve Savcılık tarafından takipsizlik kararı verilemeden konunun mahkemeye bırakılması, bu haktan yararlanan kişilerin hükümden istifade amaçları açısından çelişki teşkil ettiği gibi itibarlarının korunması amacına da hizmet etmemektedir. Ayrıca bu durum, CMK'da savcıya tanınan takdir yetkisini de işlevsiz hale getirmektedir. Yapılacak bir yasal değişiklik ile soruşturma öncesi etkin pişmanlıktan faydalanılması halinde kamu davası açılmayacağının hükme bağlanması yerinde olacaktır.

Etkin pişmanlık öngörülen suçların iştirak halinde işlenmesi durumunda, hükmün tatbikinin ne şekilde olacağı sorununun çözümünde, piyasa dolandırıcıllğı suçu açısından haktan faydalanmak isteyen her failin ayrı ayrı ödemesi gereken tutarı Hazineye ödeyerek etkin pişmanlıktan faydalanabileceği, bu meyanda pişmanlığın sirayetinin uygulama alanı bulmaması gerektiği, ancak örtülü kazanç aktarımı suçu açısından ise lafzi yoruma sıkı sıkıya bağlı kalmadan ve hükmün tatbik

U.S.C. (2002) Sarbanes-Oxley Act, Section 308(a) <https://pcaobus.org/About/History/Documents/PDFs/Sarbanes_ Oxley_Act_of_2002.pdf> accessed 31 August 2021. Fonda toplanan paraya oranla yatırımcı sayısının çok fazla olması durumunda ise bu sistemde de mağdur olan yatırımcilara dağıtım yapılamaması söz konusu olduğundan, fona aktarılacak olan paranın Hazine'ye verilmesi söz konusudur. Report Pursuant to Section 308(c) of the Sarbanes Oxley Act of 2002. <http://www.sec.gov/news/studies/sox308creport.pdf.> accessed 30 August 2021.

64 Coşkun (n 23) 184-185; Türkiyéde yatırımcıların tazmini ve Fair Fund uygulaması kapsamında öneriler ile ceza uygulamalarına ilişkin değerlendirmeler konusunda bkz. Erman Çete, 'Yatırımcı Mağduriyetinin Giderilmesinde ABD Fair Fund Uygulamasının Türkiye İçin Analizi' (Sermaye Piyasası Kurulu Yeterlik Etüdü, Mart 2013) <https://www.spk. gov.tr/SiteApps/Yayin/YayinGoster/1089> Erişim Tarihi: 30 Ağustos 2021, 52-59. 
kabiliyetini artırmak amacıyla, şirket zararı şeriklerinden biri ya da birkaçı tarafından giderildikten sonra, tespit edilen örtülü kazanç aktarımı tutarının iki katının Hazine’ye her fail tarafından ayrı ayrı ödenmesi yerine münferiden ya da müştereken anılan tutarın Hazine’ye ödenmesi halinde tüm şeriklerin etkin pişmanlıktan faydalandırılarak pişmanlığın sirayet ettirilmesinin yerinde olacağı, nihai olarak hükmün uygulanabilir hale getirilmesi amacıyla şeriklerin pişmanlığı ile mağdurun zararının giderilmesi amaçları arasındaki dengeyi muhafaza edecek yasal değişiklik yapılmasının uygun olacağı kanaatindeyiz. Bu çerçevede ayrıca her iki suç açısından da menfaat tutarları ile örtülü kazanç aktarımı tutarlarının sağlıklı ve doğru bir şekilde, imkân ölçüsünde fail bazında ayrıştırılarak belirlenmesi hem hükmün etkin bir şekilde tatbiki hem de yargılamada verilecek kararların sıhhati açısından son derece önemlidir.

SPK'da öngörülen etkin pişmanlık kurumunun, sermaye piyasasının nev-i şahsına münhasır işleyişi ve hususiyetleri de dikkate alınarak tatbik-i kabil hale getirilmesi hükmün etkin işleyişine katkı sağlayacağı gibi doktrinde öngörüldüğü şekilde uzlaşma, ön ödeme vs. gibi alternatif yolların sermaye piyasası mevzuatı kapsamında işlenen suçlar açısından uygulanabilir bir şekilde tasarlanması da dikkate alınabilecek bir öneri olarak değerlendirilebilecektir.

Son olarak, etkin pişmanlık kapsamında tahsil edilen paraların Hazine’ye ödenmesi uygulaması yerine, suçtan zarar gören ve bunun belirlenebildiği yatırımcıların tazmini amacına tahsis edilmesi ve bu bağlamda ayrı özel bir fon oluşturulması ya da Yatırımcı Tazmin Merkezi nezdinde bu amaca özgü bir fon kurularak yatırımcı zararlarının kısmen ya da tamamen giderilmesi, hem etkin pişmanlığın amacı ve felsefesine daha uygun olacak hem de yatırımcıların tazmini için kullanılabilecek fon miktarını arttırarak piyasalara olan güvenin tezyidine imkân sağlayacaktır.

\section{KAYNAKÇA}

Arslantürk M, Etkin Pişmanlık Vazgeçme Cezasızlık (Seçkin 2018).

Artuk ME, Gökcen A, Alşahin ME ve Çakır K, Ceza Hukuku Genel Hükümler, (15. Baskı, Adalet 2021).

Artuk ME, Gökcen A, Alşahin ME ve Çakır K, Ceza Hukuku Özel Hükümler, (19. Baskı, Adalet 2021).

Baba Y, 'Türk Ceza Kanununda Etkin Pişmanlık', (Yüksek Lisans Tezi, İstanbul Üniversitesi 2011).

Balan A, Ekonomik Bir Suç Olarak Sermaye Piyasası Kanununda Düzenlenen İşleme Dayalı Piyasa Dolandırıcılĭgı Suçu, (On İki Levha 2019).

Baki E, 'Türk Ceza Kanununda Etkin Pişmanlık' (2016) (2) Yıldırım Beyazıt Hukuk Dergisi 27-56 <https:// dergipark.org.tr/tr/download/article-file/227124> Erişim tarihi 1 Eylül 2021.

Bekar E, 'Ceza Muhakemesinde Hüküm Çeşitleri (CMK m. 223’ (2017) LXXV (1) İstanbul Üniversitesi Hukuk Fakültesi Mecmuası 15-60.

Bıçak V, Ceza Muhakemesi Hukuku, (4. Baskı, Seçkin 2018).

Birtek F, 'Cumhuriyet Savcısı'nın Delilleri ve Fiili Takdir Yetkisi' (2013) 19 (2), Marmara Üniversitesi Hukuk Fakültesi Hukuk Araştırmaları Dergisi (Prof. Dr. Nur Centel’e Armağan) 953-990.

Canpolat C, 'Uygulamaya Bakan Yönleriyle Piyasa Dolandırıcılı̆̆ı Suçu' (2019) 5. Türk-Kore Ceza Hukuku Günleri, Karşılaştırmalı Hukukta Ekonomik Suçlar Sempozyumu 1-34.

Centel N ve Zafer H, Ceza Muhakemesi Hukuku, (20. Bask1, Beta 2021). 
Coşkun S, Sermaye Piyasası Hukukunda Piyasa Dolandırııllğı suçu (6362 Sayılı SPKn. Md. 107), (On İki Levha 2021).

Çete E, 'Yatırımcı Mağduriyetinin Giderilmesinde ABD Fair Fund Uygulamasının Türkiye İçin Analizi' (Sermaye Piyasası Kurulu Yeterlik Etüdü, Mart 2013) <https:/www.spk.gov.tr/SiteApps/Yayin/YayinGoster/1089> Erişim Tarihi: 30 Ağustos 2021.

Deniz İ, Ceza Muhakemesinde Hüküm, (Seçkin 2014).

Duman B, Sermaye Piyasası Kanunu’nda Piyasa Dolandırıcılĭ̆ı (Manipülasyon) Suçu (Adalet 2020).

Duran A, Örtülü Kazanç Aktarımı Yasağı (SerPK m. 21) (On İki Levha 2021).

Eker H, 'Mala Karşı İşlenen Suçlarda Etkin Pişmanlık (5237 sayılı TCK’nın 168. maddesi)' (2012) (100) Türkiye Barolar Birliği Dergisi 363-388. <http://tbbdergisi.barobirlik.org.tr/m2012.100.1192 363-388> Erişim Tarihi 1 Eylül 2021.

Ertemür H, Ceza Muhakemesi Hukukunda Alternatif Bir Çözüm Yolu Olarak Uzlaştırma, (Seçkin 2021).

Evik AH, 6362 Sayılı Sermaye Piyasası Kanunu’nda Düzenlenen (SerPK md 110/1-b ve c) Örtülü Kazanç Aktarımı Suçu (On İki Levha 2021).

Feyzioğlu M, ‘Ceza Muhakemesi Kanunu’na Göre İddianamenin Hazırlanması ve Kabulüne İlişkin Bazı Düşünceler' (2006) 1 (1) Ceza Hukuku Dergisi 31-36.

Gödekli M, 'Türk Ceza Öğretisi ve Uygulamasında Etkin Pişmanlık', (2017) 7 (29) Türkiye Adalet Akademisi Dergisi, 277-360 <https://kutuphane.dogus.edu.tr/mvt/pdf.php?pdf=0020438\&lng=0> Erişim Tarihi: 1 Eylül 2021.

Gökcen A, Balcı M, Alşahin ME ve Çakır K, Ceza Muhakemesi Hukuku, (5. Baskı, Adalet 2021).

Karacan Aİ, Sermaye Piyasası Hukuku Yazılar Cilt I, (Legal 2017).

Kıldan İT, 'Malvarlığına Karşı İşlenen Suçlarda Etkin Pişmanlık Hükmünün Uygulanabilme Koşulları' (2012) 3

(8) Türkiye Adalet Akademisi Dergisi 115-139.

Koca M ve Üzülmez İ, Türk Ceza Hukuku Genel Hükümler, (14. Bask1, Seçkin 2021).

Koca M ve Üzülmez İ, Türk Ceza Hukuku Özel Hükümler, (7. Baskı, Adalet 2020).

Kurşun G, Ceza Muhakemesinde Hüküm, (Seçkin 2016).

Memiş T ve Turan G, Sermaye Piyasası Hukuku, (5. Baskı, Seçkin 2020).

Özbek M, 'Ceza Muhakemesi Kanununda Yapılan Değiş̧iklikler Çerçevesinde Mağdur Fail Uzlaştırmasının Usul ve Esaslari' (2007) 56 (4) 123-205.

Özbek VÖ, Ekonomi Ceza Hukuku Birinci Kitap-Genel Hükümler (2. Baskı, Seçkin 2021).

Özbek VÖ, Doğan K ve Bacaksız P, Türk Ceza Hukuku Genel Hükümler, (12. Baskı, Seçkin 2021).

Özen M, Öğreti ve Uygulama Işı̆̆ında Ceza Hukuku Özel Hükümler Cilt II, (2. Bask1, Adalet 2021).

Özen M, 'Kamu Davası Açma Konusunda Benimsenen İlkeler, Cumhuriyet Savcısının Takdir Yetkisi ve İddianamenin İadesi' (2009) 67 (3) 17-28.

Özer İ, 'Türk Ceza Hukukunda Etkin Pişmanlık' (Yüksek Lisans Tezi, Selçuk Üniversitesi 2011).

Özgenç İ, Türk Ceza Hukuku Genel Hükümler, (17. Baskı, Seçkin 2021).

Özgenç İ ve Ölmez G, 'Sermaye Piyasasında Güveni Korumaya Yönelik Yükümlülükler ve Ceza Hukuku Sorumluluğu' (2019) 5. Türk-Kore Ceza Hukuku Günleri, Karşılaştırmalı Hukukta Ekonomik Suçlar Sempozyumu 1-46.

Sarbanes-Oxley Act of 2002, Pub. L. No. 107-204, 116 Stat. 745 (codified as amended in scattered sections of 15, 18 U.S.C. (2002) Sarbanes-Oxley Act, Section 308(a). <https://pcaobus.org/About/History/Documents/ PDFs/Sarbanes_Oxley_Act_of_2002.pdf > accessed 31 August 2021.

Sadak M, Sermaye Piyasası Hukukunda Örtülü Kazanç Aktarımı Suçu, (Legal 2016). 
Report Pursuant to Section 308(c) of the Sarbanes Oxley Act of $2002<$ http://www.sec.gov/news/studies/ sox308creport.pdf.> accessed 30 August 2021.

Tok A, Sermaye Piyasası Kurulunun Halka Açık Şirketleri Denetlemesi (İksad 2021).

Turan G, 'Etkin Pişmanlık ve 6362 Sayılı Sermaye Piyasası Kanunu’nda Yeri' (2013) (13) Sermaye Piyasası Dergisi 106-115.

Yenidünya AC, 'SPK'da Düzenlenen Suç ve Kabahatlere İlişskin Genel Prensipler' iç A. Caner Yenidünya, Mustafa Erkan ve Rayhan Asat (edr), İpek Yolu Canlanıyor-Türk Çin Hukuku Zirvesi (Adalet 2013) 85-96.

Yenidünya AC, 'Malvarlığına Karşı Suçlarda Etkin Pişmanlık ve Uygulaması' <https://caneryenidunya.com/ malvarligina-karsi-suclarda-etkin-pismanlik/> Erişim Tarihi: 1 Eylül 2021.

Yenisey F ve Nuhoğlu A, Ceza Muhakemesi Hukuku, (9. Baskı, Seçkin 2021).

Yıldırım E, Sermaye Piyasası Suçları Açısından Etkin Pişmanlık, Sermaye Piyasası Kurulu Yeterlik Etüdü (Hizmete Özel), (2013).

Lexpera İçtihat Bilgi Bankası 